\title{
International Union of Basic and Clinical Pharmacology. LXXXVIII. G Protein-Coupled Receptor List: Recommendations for New Pairings with Cognate Ligands
}

Anthony P. Davenport, Stephen P. H. Alexander, Joanna L. Sharman, Adam J. Pawson, Helen E. Benson, Amy E. Monaghan, Wen Chiy Liew, Chidochangu P. Mpamhanga, Tom I. Bonner, Richard R. Neubig, Jean Philippe Pin, Michael Spedding, and Anthony J. Harmar

Clinical Pharmacology Unit, University of Cambridge, Cambridge, United Kingdom (A.P.D.); School of Biomedical Sciences, University of Nottingham Medical School, Nottingham, United Kingdom (S.P.H.A.); The University/BHF Centre for Cardiovascular Science, The Queen's Medical Research Institute, University of Edinburgh, Edinburgh, United Kingdom (J.L.S., A.J.P., H.E.B., A.E.M., W.C.L., C.P.M., A.J.H.);

Section on Functional Neuroscience, National Institute of Mental Health, Bethesda, Maryland (T.I.B.); Department of Pharmacology, University of Michigan, Ann Arbor, Michigan (R.R.N.); Department of Molecular Pharmacology, Institute of Functional Genomics, CNRS UMR5203, Universities Montpellier, Montpellier, France (J.P.P.); and Les Laboratoires Servier, Suresnes, France (M.S.)

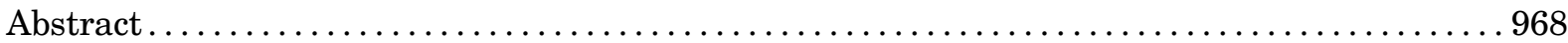

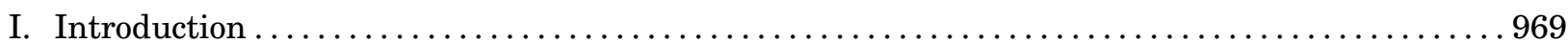

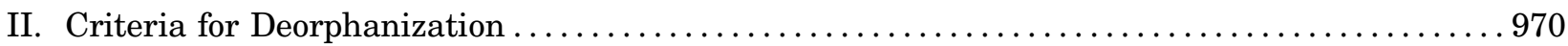

III. Recommendations for Formal Receptor Nomenclature Based on New Pairings of Orphan

Receptors with Cognate Ligands . . . . . . . . . . . . . . . . . . . . . . . . . . 972

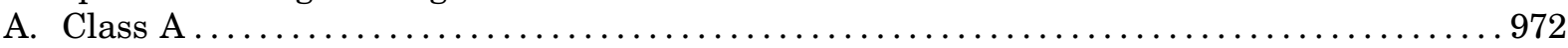

1. Hydroxycarboxylic Acid Receptors: $\mathrm{HCA}_{1}\left(\right.$ GPR81)/Lactate, $\mathrm{HCA}_{2}$

(GPR109A)/3-Hydroxybutyric Acid, and $\mathrm{HCA}_{3}($ GPR 109B)/3-Hydroxyoctanoic Acid . . . 972

2. Lysophosphatidic Acid Receptors: $\mathrm{LPA}_{4}\left(\right.$ GPR23), $\mathrm{LPA}_{5}$ (GPR92), and $\mathrm{LPA}_{6}(P 2 Y 5) \ldots 973$

3. FFA4 (GPR120) and Omega-3 Fatty Acids..........................973

4. The Chemerin Receptor (Chemokine-like Receptor; CMKLR1; ChemR23) and Chemerin .973

5. CXCR7 (CMKOR1) with CXCL12 (SDF-1) and CXCL11 (ITAC) ................974

6. Succinate Receptor (SUCNR1 GPR91) with Succinate; Oxoglutarate Receptor (OXGR1 GPR99) with 2-Oxoglutarate $(\alpha$-Ketoglutarate) . . . . . . . . . . . . . . . . 974

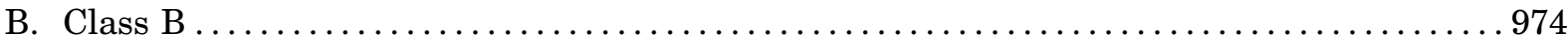

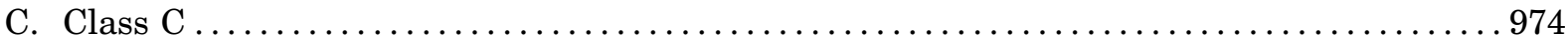

IV. Pairings of Orphan Receptors with Cognate Ligands Reported by a Single Paper or Where

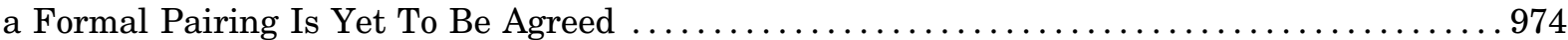

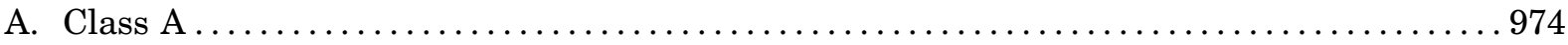

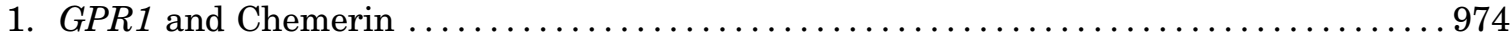

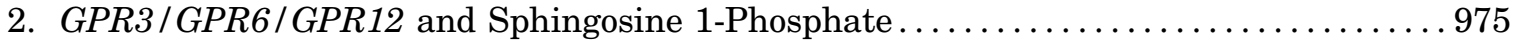

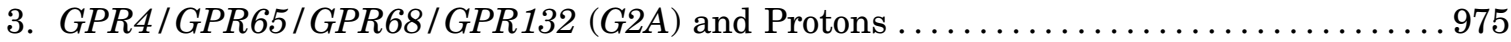

4. GPR17: Dual Receptor for Cysteinyl Leukotrienes/Nucleotides. . . . . . . . . . . . .975

5. GPR18 and $N$-Arachidonoylglycine, Cannabinoid Ligands . . . . . . . . . . . . 975

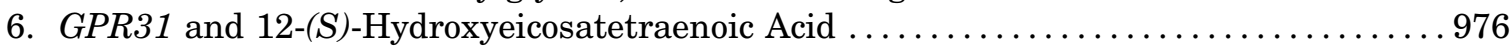

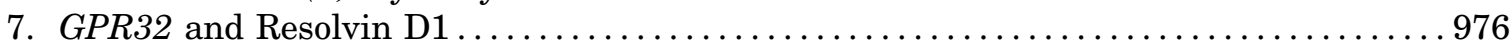

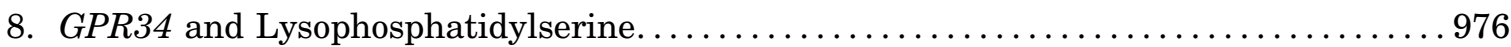

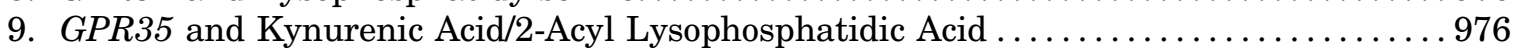

This work was supported in part by the Wellcome Trust [Grants 268427, 085686/2/08; Biomedical Resources Grant 099156/Z/12/Z] for support for IUPHAR-DB (to A.H., S.P.H.A., and A.P.D.); the British Heart Foundation [Grants PS/02/001 and PG/09/050/27734] (to A.P.D.); Pulmonary Hypertension Association; the National Institute for Health Research Cambridge Biomedical Research Centre; the Intramural Research Program of the National Institutes of Health [National Institute of Mental Health] (to T.B.).

Address correspondence to: Anthony P. Davenport, Clinical Pharmacology Unit, University of Cambridge, Level 6, Centre for Clinical Investigation, Box 110, Addenbrooke's Hospital, Cambridge, CB2 0QQ, UK. E-mail: apd10@medschl.cam.ac.uk

dx.doi.org/10.1124/pr.112.007179. 
10. GPR37 and Neuropeptide Head Activator............................ 976

11. GPR39 and $\mathrm{Zn}^{2+}$ but Retraction of Obestatin as Cognate Ligand ................ 977

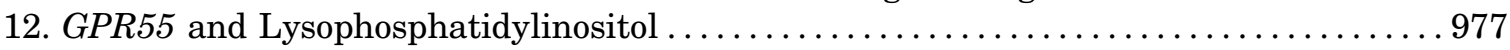

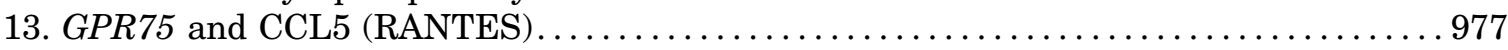

14. GPR84 and Medium-Chain FFAs ................................. 977

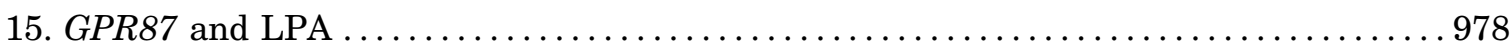

16. GPR119 and Derivatives of Oleate .................................. 978

17. GPR182 and Adrenomedullin..................................... 978

18. GPR183 (EBI2) and Oxysterols ...................................... 978

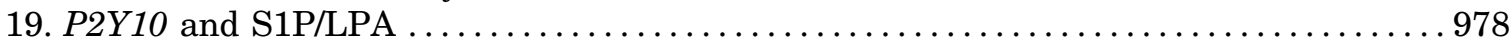

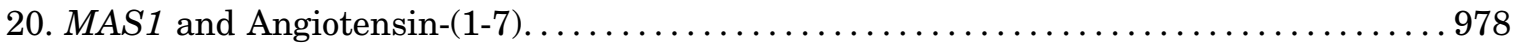

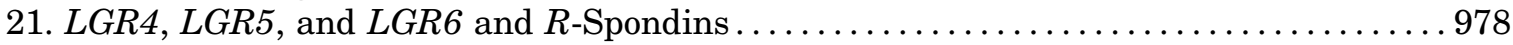

22. Mas-Related GPCRs: MRGPRD with $\beta$-Alanine; $M R G P R X 1$ with Bovine Adrenal Medulla Peptide 22 (BAM22); MRGPRX2 with Cortistatin-14............. 979

B. Class B . ...................................................... 979

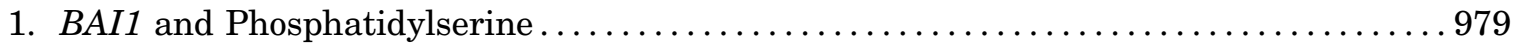

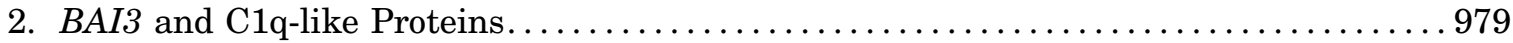

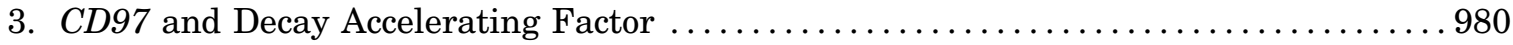

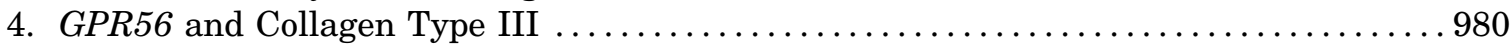

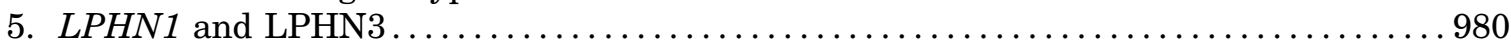

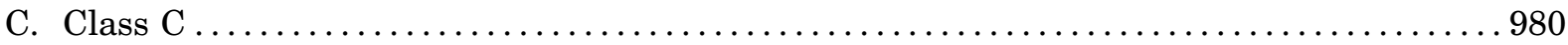

1. GPRC6A and Calcium, Amino Acids, and Osteocalcin .................... 980

V. Orphan Receptors with Activity in Absence of an Endogenous Ligand, Activation by

Surrogate Ligands, or Significant Phenotype in Genetically Modified Animals.............. 980

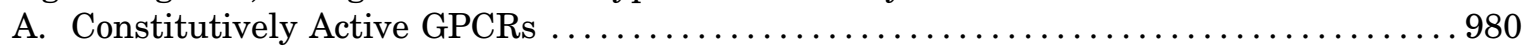

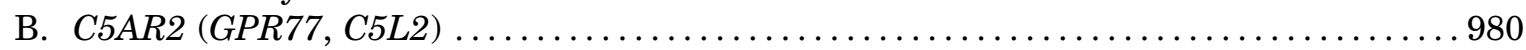

C. CCRL1 (CCX-CKR), CCRL2 (CRAM), CCBP2 (D6), and DARC .............. 980

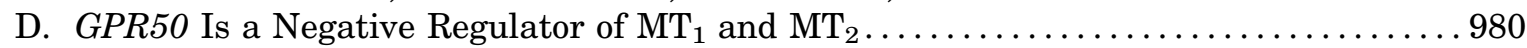

VI. Pseudogenes....................................................... 981

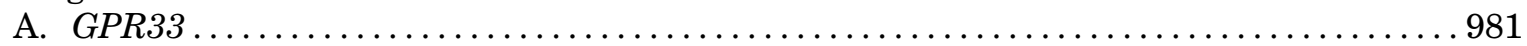

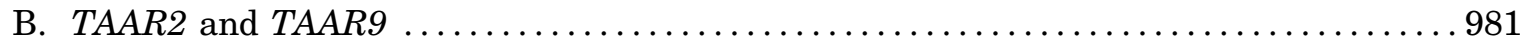

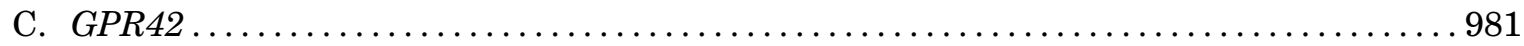

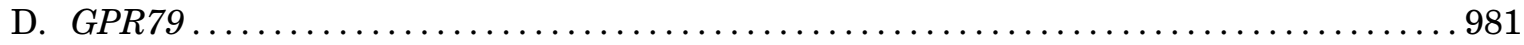

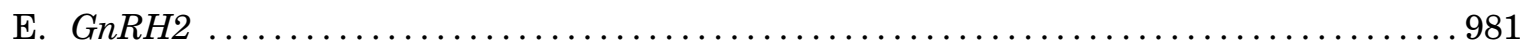

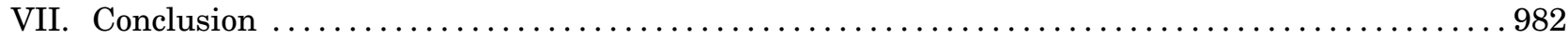

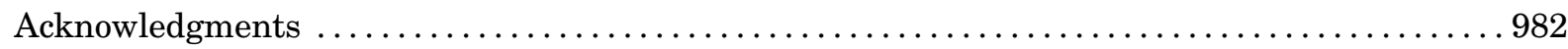

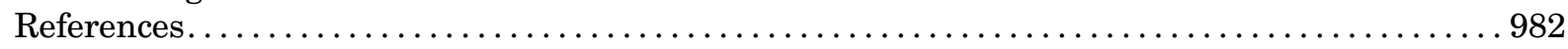

\begin{abstract}
In 2005, the International Union of Basic and Clinical Pharmacology Committee on Receptor Nomenclature and Drug Classification (NC-IUPHAR) published a catalog of all of the human gene sequences known or predicted to encode G protein-coupled receptors (GPCRs), excluding sensory receptors. This review updates the list of orphan GPCRs and describes the criteria used by NC-IUPHAR to recommend the pairing of an orphan receptor with its cognate ligand(s). The following recommendations are made for new receptor names based on 11 pairings for class A GPCRs: hydroxycarboxylic acid receptors $\left[\mathrm{HCA}_{1}\right.$ (GPR81) with lactate, $\mathrm{HCA}_{2}(G P R 109 A)$ with 3-hydroxybutyric
\end{abstract}

acid, $\mathrm{HCA}_{3}($ GPR109B) with 3-hydroxyoctanoic acid]; lysophosphatidic acid receptors $\left[\mathrm{LPA}_{4}\right.$ (GPR23), LPA (GPR92), $\mathrm{LPA}_{6}$ (P2Y5)]; free fatty acid receptors [FFA4 (GPR120) with omega-3 fatty acids]; chemerin receptor (CMKLR1; ChemR23) with chemerin; CXCR7 (CMKOR1) with chemokines CXCL12 (SDF-1) and CXCL11 (ITAC); succinate receptor (SUCNR1) with succinate; and oxoglutarate receptor [OXGR1 with 2-oxoglutarate]. Pairings are highlighted for an additional 30 receptors in class $A$ where further input is needed from the scientific community to validate these findings. Fiftyseven human class A receptors (excluding pseudogenes) are still considered orphans; information has been

ABBREVIATIONS: Ang-(1-7), angiotensin-(1-7); BAM22, bovine adrenal medulla peptide 22; CMKLR1, chemokine-like receptor 1; CysLT, cysteinyl leukotriene; ERK, extracellular signal-regulated kinase; FFA, free fatty acid; GLP-1, glucagon-like peptide-1; GPCR, G proteincoupled receptor; HCA, hydroxycarboxylic acid; 12-(S)-HETE, 12-(S)-hydroxyeicosatetraenoic acid; ID no., identification number; ITAC, interferon-inducible T-cell $\alpha$ chemoattractant; LPA, lysophosphatidic acid; LPI, lysophosphatidylinositol; LysoPS, lysophosphatidylserine; MRG, Mas-related GPCR; NAGly, $N$-arachidonoylglycine; NC-IUPHAR, International Union of Basic and Clinical Pharmacology Committee on Receptor Nomenclature and Drug Classification; $7 \alpha, 25$-OHC, $7 \alpha, 25$-dihydroxycholesterol; PAMP-20, proadrenomedullin N-terminal 20 peptide; RvD1, resolvin D1; S1P, sphingosine 1-phosphate; SDF-1, stromal cell-derived factor-1. 
provided where there is a significant phenotype in genetically modified animals. In class $B$, six pairings have been reported by a single publication, with 28 (excluding pseudogenes) still classified as orphans. Seven orphan receptors remain in class $C$, with one pairing described by a single paper. The objective is to stimulate research into confirming pairings of orphan receptors where there is currently limited information and to identify cognate ligands for the remaining GPCRs. Further information can be found on the IUPHAR Database website (http://www.iuphar-db. org).

\section{Introduction}

The sequencing of the human genome has allowed the IUPHAR (International Union of Basic and Clinical Pharmacology) Committee on Receptor Nomenclature and Drug Classification (NC-IUPHAR) to catalog all of the human gene sequences potentially encoding $\mathrm{G}$ protein-coupled receptors (GPCRs), excluding sensory receptors. In addition to established transmitter systems, the classification in Pharmacological Reviews (see Foord et al., 2005) and in the IUPHAR Database (IUPHAR-DB) (see Sharman et al., 2011) included "orphan" GPCRs for which the endogenous ligand(s) was not known. Since this publication, considerable progress has been made in screening artificially expressed receptors to identify the cognate endogenous ligand (for example, see Zhang et al., 2011; Civelli, 2012; Yoshida et al., 2012). Where understanding of the physiology, pharmacology, and pathology has begun to emerge, the receptor has been officially classified and named (usually after the endogenous ligand following IUPHAR nomenclature conventions) and published in Pharmacological Reviews (http://www.iuphar-db. org/nciupharPublications.jsp). Physiologic functions have now been assigned to a number of receptors previously designated as orphans. These include the family of free fatty acid receptors (FFA1-FFA3) (Stoddart et al., 2008); neuropeptide B and W as ligands NPBW1 (GPR7) and NPBW2 (GPR8) (Singh and Davenport, 2006); the protein encoded by the APJ gene (Ishida et al., 2004), now classified as the apelin receptor (Pitkin et al., 2010); GPR30 as the estrogen GPCR (GPER) (Revankar et al., 2005; Thomas et al., 2005; Wang et al., 2008; Martensson et al., 2009; Prossnitz and Barton, 2011); GPR54 as the kisspeptin receptor (Kirby et al., 2010); GHS-R1a as the ghrelin receptor (Davenport et al., 2005); the $\mathrm{TA}_{1}$ receptor activated by endogenous trace amine ligands, including tyramine (IUPHAR-DB no. 2150) and $\beta$-phenylethylamine (IUPHAR-DB no. 2144) (Maguire et al., 2009); and GPR131 as the bile acid receptor (GPBA) (Maruyama et al., 2002). This review extends the number of receptors where these criteria have been met, particularly where replicated by independent groups, which are shown for class A GPCRs in Table 1.

To reflect the dynamic nature of the field, where a single paper exists describing a new pairing, a list is maintained on IUPHAR-DB (http://www.iuphar-db.org/ latestPairings.jsp) (Table 2). This review also reports on a third group still considered orphans (Table 3 ). In a small number of instances, the pairing is retracted because it cannot be repeated. In some cases, "surrogate" ligands for orphan GPCRs (drugs or small molecules that can be used as tool compounds that act on targets for which the endogenous ligand is not yet known) have been identified, and these can be used as pharmacological tools to explore the function and therapeutic potential of these proteins. The alternative approach is to focus on significant phenotypes in genetically modified animals, and this information has been included. Orphan GPCRs have been identified that have activity in the absence of an endogenous ligand or work in concert with other receptors and may not have a cognate endogenous ligand. Finally, a small number of genes are listed, initially identified as orphan GPCRs, which are pseudogenes, at least in some individuals.

Thirty human receptors in class A are currently supported by a single publication; or where there is more than one independent publication, the results are not concordant or relevant committees are waiting for the accumulation of unequivocal pharmacological evidence for a formal adoption of nomenclature. Fifty-seven receptors (excluding pseudogenes) are still considered orphans. In class B, six pairings have been reported by a single publication, with an additional 28 (excluding pseudogenes) still classified as orphans. Seven orphan receptors remain in class $\mathrm{C}$, with one pairing described by a single paper.

A number of orphan GPCRs were able to be deorphanized because of their close similarity to other receptors or paralogs. These are thought to have arisen by gene duplication and might therefore be expected to have similar ligands. Some of the receptors described in this review are groups of paralogs such as GPR3, GPR6, and GPR12. Conversely, however, GPCRs with disparate evolutionary origins can bind and respond to the same ligands. For example, the relaxins are able to activate RXFP1 and -2, which are 757 and 737 amino acids in length and share $\sim 60 \%$ amino acid sequence similarity, with 10 leucine-rich repeats in their large N-terminal extracellular domains. In contrast, RXFP3 and -4, which are also activated by relaxins, have short $\mathrm{N}$-terminal extracellular domains and contain only 469 and 374 amino acid residues. Receptors have been listed alphabetically in the tables, and reviews (including Lagerström and Schiöth, 2008; Strotmann et al., 2011) should be consulted for detailed analysis of the phylogenetic relationships.

We have endeavored to identify all key papers reporting pairings by carrying out systematic searches, using current as well as previous gene names for the orphan receptors in classes $\mathrm{A}, \mathrm{B}$, and $\mathrm{C}$ as they appear 
TABLE 1

Recommendations for formal receptor nomenclature based on new pairings of class A orphan receptors with cognate ligands

Gene symbols are those approved by the HUGO Gene Nomenclature Committee (http://www.genenames.org/) (Seal et al., 2011). Where the phenotype of the knockout mouse has been published, this is indicated: Further information can be obtained from the IUPHAR Database (http://www.iuphar-db.org/) (Sharman et al., 2011) and the Mouse Genome Database at Mouse Genome Informatics (Eppig et al., 2012).

\begin{tabular}{|c|c|c|c|c|c|}
\hline Endogenous Ligand & $\begin{array}{l}\text { Official IUPHAR } \\
\text { Nomenclature }\end{array}$ & $\begin{array}{c}\text { Previous } \\
\text { Nomenclature }\end{array}$ & $\begin{array}{c}\text { Approved } \\
\text { Human } \\
\text { Gene Symbol }\end{array}$ & $\begin{array}{l}\text { Knockout } \\
\text { Mouse }\end{array}$ & $\begin{array}{l}\text { Phenotype } \\
\text { Reported }\end{array}$ \\
\hline Chemerin (RARRES2, resolvin E1, TIG2) & Chemerin & CMKLR1 & $C M K L R 1$ & Yes & Yes \\
\hline CXCL12 (SDF-1), CXCL11 (ITAC) & CXCR7 & CMKOR1 & CXCR7 & Yes & Yes \\
\hline Omega-3 fatty acids & FFA4 & GPR120/GPR129 & $O 3 F A R 1$ & Yes & Yes \\
\hline Lactate & $\mathrm{HCA}_{1}$ & GPR81/GPR104 & $H C A R 1$ & Yes & Yes \\
\hline D- $\beta$-Hydroxybutyrate & $\mathrm{HCA}_{2}$ & GPR109A & HCAR2 & Yes & Yes \\
\hline 3-Hydroxyoctanoate & $\mathrm{HCA}_{3}$ & GPR109B & $H C A R 3^{a}$ & No & \\
\hline LPA & $\mathrm{LPA}_{4}$ & GPR23 & LPAR4 & Yes & Yes \\
\hline LPA & $\mathrm{LPA}_{5}$ & GPR92/GPR93 & LPAR5 & Yes & Yes \\
\hline LPA & $\mathrm{LPA}_{6}$ & P2RY5 & LPAR6 & No & \\
\hline 2-Oxoglutarate & Oxoglutarate & GPR91 & OXGR1 & No & \\
\hline Succinate & Succinate & GPR99 & SUCNR1 & Yes & Yes \\
\hline
\end{tabular}

${ }^{a}$ Gene absent in mice.

in the IUPHAR-DB. It is not possible to include all papers that refer to some aspect of a particular orphan receptor, but where appropriate and where they exist, we have added selected references to more detailed reviews, which should be consulted for further information. To provide readers with access to a wide range of chemical information and the biologic activity data for the ligands listed in this review, IUPHAR-DB Ligand identification numbers (ID no.) are provided (within parentheses). Readers may either enter the Ligand ID no. into the "Quick text search" box on the IUPHAR-DB website (http://www.iuphar-db.org) or navigate to the ligand search tools page (http://www.iuphar-db.org/ DATABASE/chemSearch.jsp) and select "IUPHAR/GRAC Ligand ID" in the "Chemical identifier" search box. The review excludes sensory receptors, which are curated by the Olfactory Receptor DataBase (ORDB) (http://senselab. med.yale.edu/ordb/).

\section{Criteria for Deorphanization}

Several criteria are used by NC-IUPHAR in considering the assignment of an endogenous ligand to a receptor. Firstly, two or more refereed papers from independent research groups should demonstrate activity of the ligand at the receptor, with a potency that is consistent with a physiologic function. Reproducibility of the pairing is the minimum criterion, particularly to avoid false positives that might arise in high-throughput screens or for other reasons. In some cases, although two independent groups have reported a pairing, others have failed to reproduce this. We have indicated where pairings remain controversial to identify areas where more research is required for NC-IUPHAR to make a definitive statement and that are under active consideration by the relevant subcommittees. Occasionally, reported pairings are retracted, and these are recorded on the IUPHAR-DB (http://www.iuphar-db. org/latestPairings.jsp).

As a particular field evolves, the following additional criteria may support and strengthen the initial pairing, although it is recognized that these are exacting and are unlikely to be met in all instances. Preferably, both radioligand binding (although it is recognized that some endogenous ligands may not be suitable for labeling or the density of receptors may be too low to detect) and functional assays should be employed, both in vitro and in native tissues. Selective agonists should mimic and selective antagonists should block the action of the endogenous ligand. Secondly, the putative endogenous ligand should be present in tissues in appropriate concentrations. Further evidence for the pairing of orphan GPCRs with cognate endogenous ligands may be obtained at the anatomic level; there should be plausible mechanisms for the proposed ligand to reach physiologically significant concentrations in tissues expressing its cognate receptor, either through local synthesis or by transport to the tissue, e.g., as a hormone. For neuropeptides, indirect techniques such as immunocytochemistry and in situ hybridization of the precursor mRNA can provide useful evidence. Small molecules that are candidate ligands for receptors may be detected using a variety of techniques including radioimmunoassay and mass spectrometry associated with gas chromatography or high-performance liquid chromatography. Deleting the gene encoding the receptor in mice, exploiting a naturally occurring deletion in human tissues, or RNA silencing should abolish receptor characteristics, such as radioligand binding or physiologic/pharmacological actions of the endogenous ligand in functional assays. Conversely, receptor overexpression may be expected to potentiate these actions.

Many of the recently proposed ligands are lipids, which pose distinct difficulties for assignation as endogenous orthosteric ligands. Firstly, concentration-response relationships are almost always difficult to assess due to detergent and surfactant effects, binding to proteins such as albumin, and formation of micelles. Secondly, by modification of membrane properties or insertion into membranes, lipids can block or reveal the effects of allosteric modulators; membrane interactions can also 
TABLE 2

Reported pairings of orphan receptors with cognate ligands reported by a single paper

Gene symbols are those approved by the HUGO Gene Nomenclature Committee (http://www.genenames.org/) (Seal et al., 2011). Where the phenotype of the knockout mouse has been published, this is indicated: Further information can be obtained from the IUPHAR Database (http:// www.iuphar-db.org/) (Sharman et al., 2011) and the Mouse Genome Database at Mouse Genome Informatics (Eppig et al., 2012).

\begin{tabular}{|c|c|c|c|}
\hline Putative Endogenous Ligand & $\begin{array}{l}\text { Approved Human } \\
\text { Gene Symbol }\end{array}$ & Knockout Mouse & Phenotype Reported \\
\hline \multicolumn{4}{|l|}{ Class A } \\
\hline Chemerin & GPR1 & Yes & No \\
\hline S1P & GPR3 & Yes & Yes \\
\hline Protons & GPR4 & Yes & Yes \\
\hline $\mathrm{S} 1 \mathrm{P}$ & GPR6 & Yes & Yes \\
\hline $\mathrm{S} 1 \mathrm{P}$ & GPR12 & Yes & Yes \\
\hline \multicolumn{4}{|l|}{$\mathrm{D}_{4}, \mathrm{UDP}, \mathrm{UDP}$-galactose) } \\
\hline NAGly & GPR18 & No & \\
\hline 12-(S)-HETE & $G P R 31^{a}$ & No & \\
\hline RvD1 & $G P R 32^{a}$ & No & \\
\hline LPS & GPR34 & Yes & Yes \\
\hline Kynurenic acid, 2-acyl LPA & GPR35 & No & \\
\hline Neuropeptide head activator $b$ & GPR37 & Yes & Yes \\
\hline $\mathrm{Zn}^{2+}+1$ & GPR39 & Yes & Yes \\
\hline L- $\alpha$-LPI & GPR55 & Yes & Yes \\
\hline Protons & GPR65 & Yes & Yes \\
\hline Protons & GPR68 & Yes & Yes \\
\hline CCL5 (RANTES) & GPR75 & No & \\
\hline Medium-chain fatty acids & GPR84 & Yes & Yes \\
\hline LPA & GPR87 & Yes & Yes \\
\hline Oleoylethanolamide & GPR119 & Yes & Yes \\
\hline Protons & GPR132 & Yes & Yes \\
\hline Oxysterols & $G P R 183$ & Yes & Yes \\
\hline R-spondins & $L G R 4$ & Yes & Yes \\
\hline R-spondins & LGR5 & Yes & Yes \\
\hline R-spondins & $L G R 6$ & No & \\
\hline Ang-(1-7) & MAS1 & Yes & Yes \\
\hline$\beta$-Alanine & $M R G P R D$ & Yes & Yes \\
\hline BAM22 & $M R G P R X 1^{c}$ & No & \\
\hline Cortistatin, PAMP & $M R G P R X 2^{c}$ & No & \\
\hline LPA, S1P & $P 2 R Y 10$ & No & \\
\hline \multicolumn{4}{|l|}{ Class B } \\
\hline Phosphatidylserine & $B A I 1$ & No & \\
\hline C1q-like proteins & BAI3 & No & \\
\hline Decay accelerating factor & $C D 97$ & Yes & No \\
\hline Collagen type III & GPR56 & Yes & Yes \\
\hline Neurexins, teneurin-2 & LPHN1 & Yes & Yes \\
\hline FLRT3 & LPHN3 & Yes & No \\
\hline \multicolumn{4}{|l|}{ Class C } \\
\hline Calcium, amino acids, and osteocalcin & GPRC6A & Yes & Yes \\
\hline
\end{tabular}

${ }^{a}$ Pseudogene in mice.

${ }^{b}$ See discussion in text as to whether neuropeptide head activator is an endogenous ligand.

${ }^{c}$ Gene absent in mice.

drive allosteric changes in receptor conformation and also change the surface charge around channels and receptors. Studies of the crystal structure of the $\mathrm{S}_{1} \mathrm{P}_{1}$ receptor fused to T4 lysozyme in complex with an antagonist sphingolipid mimic have been particularly instructive (Hanson et al., 2012). Lipid ligands are thought to gain access to the binding pocket from within the membrane bilayer rather than from the extracellular compartment.

In parallel, there has been a major revolution in lipid metabolomics, with up to 3000 lipids being detectable in small biologic membrane samples, and precise changes of these lipids may be followed in, for example, pathologic situations. However, this expensive methodology has not been applied to any of the studies claiming lipids as the endogenous agonists of receptors, so the question of whether closely related lipids may be more preponderant (and active) than the studied species is a clear concern for nomenclature. NC-IUPHAR will continue to apply the criteria for evaluating pairing of lipids with GPCRs that are used for non-lipid ligands but encourages authors to take these reservations into account for future studies.

In the absence of a cognate endogenous ligand, genetically modified mice and overexpression of genes encoding target receptors can provide evidence for a physiologic or pathophysiological role. For example, the GPR3 gene has been mapped to the candidate Alzheimer's disease linkage region and is predominantly expressed in the central nervous system. It is thought to be a constitutively active orphan GPCR and has been identified as a modulator of amyloid- $\beta$ production. Overexpression of GPR3 stimulated amyloid- $\beta$ production in an Alzheimer's disease mouse model, whereas knocking out the GPR3 gene prevented accumulation of the amyloid- $\beta$ peptide (Thathiah et al., 2009). 
TABLE 3

Orphan receptors

Gene symbols are those approved by the HUGO Gene Nomenclature Committee (http://www.genenames.org/) (Seal et al., 2011). Where the phenotype of the knockout mouse has been published, this is indicated: Further information can be obtained from the IUPHAR Database (http://www.iuphar-db.org/) (Sharman et al., 2011) and the Mouse Genome Database at Mouse Genome Informatics (Eppig et al., 2012).

\begin{tabular}{|c|c|c|}
\hline $\begin{array}{l}\text { Approved Human } \\
\text { Gene Symbol }\end{array}$ & Knockout Mouse & Phenotype Reported \\
\hline \multicolumn{3}{|l|}{ Class A } \\
\hline $\mathrm{BB}_{3}$ & Yes & Yes \\
\hline GPR15 & No & \\
\hline GPR19 & Yes & Yes \\
\hline GPR20 & Yes & No \\
\hline GPR21 & Yes & No \\
\hline GPR22 & Yes & Yes \\
\hline GPR25 & No & \\
\hline GPR26 & Yes & Yes \\
\hline GPR27 & No & \\
\hline$G P R 33^{a}$ & No & \\
\hline GPR37L1 & Yes & Yes \\
\hline$G P R 42^{b}, c$ & No & \\
\hline GPR45 & No & \\
\hline GPR50 & Yes & Yes \\
\hline GPR52 & No & \\
\hline GPR61 & Yes & No \\
\hline GPR62 & No & \\
\hline GPR63 & No & \\
\hline GPR78 & $\mathrm{No}^{b}$ & $b$ \\
\hline$G P R 79^{c}$ & $\mathrm{No}^{d}$ & $d$ \\
\hline GPR82 & Yes & Yes \\
\hline GPR83 & Yes & No \\
\hline GPR85 & Yes & Yes \\
\hline GPR88 & Yes & Yes \\
\hline GPR101 & No & \\
\hline GPR135 & No & \\
\hline GPR139 & No & \\
\hline GPR141 & No & \\
\hline GPR142 & No & \\
\hline GPR146 & No & \\
\hline$G P R 148^{b}$ & No & \\
\hline GPR149 & Yes & Yes \\
\hline GPR150 & No & \\
\hline GPR151 & Yes & No \\
\hline GPR152 & No & \\
\hline GPR153 & No & \\
\hline GPR160 & No & \\
\hline GPR161 & Yes & No \\
\hline GPR162 & No & \\
\hline GPR171 & No & \\
\hline GPR173 & No & \\
\hline GPR174 & No & \\
\hline GPR176 & No & \\
\hline GPR182 & No & \\
\hline$M A S 1 L^{b}$ & No & \\
\hline MRGPRE & Yes & Yes \\
\hline$M R G P R F$ & No & \\
\hline$M R G P R G$ & No & \\
\hline MRGPRX3 & $\mathrm{No}^{d}$ & \\
\hline$M R G P R X 4^{b}$ & No & \\
\hline OPN3 & No & \\
\hline OPN5 & No & \\
\hline$P 2 R Y 8^{b}$ & No & \\
\hline TAAR2 & No & \\
\hline$T A A R 3^{c}$ & No & \\
\hline$T A A R 4 P^{c}$ & No & \\
\hline TAAR5 & No & \\
\hline TAAR6 & No & \\
\hline TAAR8 & No & \\
\hline TAAR9 & No & \\
\hline \multicolumn{3}{|l|}{ Class B } \\
\hline BAI2 & Yes & Yes \\
\hline CELSR1 & Yes & Yes \\
\hline CELSR2 & Yes & Yes \\
\hline CELSR3 & Yes & Yes \\
\hline ELTD1 & Yes & No \\
\hline EMR1 & Yes & Yes \\
\hline$E M R 2^{b}$ & No & \\
\hline
\end{tabular}

TABLE 3-Continued

\begin{tabular}{|c|c|c|}
\hline $\begin{array}{l}\text { Approved Human } \\
\text { Gene Symbol }\end{array}$ & Knockout Mouse & Phenotype Reported \\
\hline$E M R 3^{b}$ & No & \\
\hline$E M R 4 P^{c}$ & No & \\
\hline GPR64 & Yes & Yes \\
\hline GPR97 & Yes & No \\
\hline GPR98 & Yes & Yes \\
\hline GPR110 & No & \\
\hline GPR111 & No & \\
\hline GPR112 & No & \\
\hline GPR113 & No & \\
\hline GPR114 & No & \\
\hline GPR115 & No & \\
\hline GPR116 & No & \\
\hline GPR123 & No & \\
\hline GPR124 & Yes & Yes \\
\hline GPR125 & Yes & No \\
\hline GPR126 & Yes & Yes \\
\hline GPR128 & No & \\
\hline GPR133 & No & \\
\hline GPR144 & No & \\
\hline GPR157 & No & \\
\hline LPHN2 & No & \\
\hline \multicolumn{3}{|l|}{ Class C } \\
\hline GPR156 & No & \\
\hline GPR158 & No & \\
\hline GPR179 & Yes & Yes \\
\hline GPRC5A & Yes & Yes \\
\hline GPRC5B & Yes & Yes \\
\hline GPRC5C & Yes & No \\
\hline GPRC5D & No & \\
\hline
\end{tabular}

The results suggest that the GPR3 protein may be a potential therapeutic target for the treatment of Alzheimer's disease, leading to the development of surrogate ligands in the absence of knowledge of the endogenous transmitter (Thathiah et al., 2009).

\section{Recommendations for Formal Receptor Nomenclature Based on New Pairings of Orphan Receptors with Cognate Ligands}

\section{A. Class A}

1. Hydroxycarboxylic Acid Receptors: $H C A_{1}$ (GPR81)/ Lactate, $\mathrm{HCA}_{2}$ (GPR109A)/3-Hydroxybutyric Acid, and $\mathrm{HCA}_{3}$ (GPR109B)/3-Hydroxyoctanoic Acid. A family of three structurally related receptors has been named the hydroxycarboxylic acid (HCA) receptors (Offermanns et al., 2011). $\mathrm{HCA}_{1}$ (GPR81) is activated by lactic acid (IUPHAR-DB ID nos. 2932, 2934) (Cai et al., 2008; Ahmed et al., 2010), $\mathrm{HCA}_{2}$ (GPR109A; also known as PUMA- $G$ ) by $\beta$-D-hydroxybutyric acid (IUPHAR-DB ID no. 1593) (Taggart et al., 2005), and $\mathrm{HCA}_{3}$ (GPR109B; also known as HM74) is activated by the $\beta$-oxidation intermediate 3-hydroxyoctanoic acid (IUPHAR-DB ID no. 2933) (Ahmed et al., 2009). The endogenous ligands of these receptors are unusual as they are of relatively low potency (in the millimolar range) compared with other endogenous GPCR ligands, although the endogenous ligand of $\mathrm{HCA}_{3}$ (3-hydroxyoctanoic acid) activates its receptor at micromolar concentrations. $\mathrm{HCA}_{2}$ and $\mathrm{HCA}_{3}$ are also activated by nicotinic 
acid (Tunaru et al., 2003). This receptor family was first named the nicotinic acid receptor family. However, this nomenclature is inappropriate because nicotinic acid is not an endogenous ligand. $\mathrm{HCA}_{1}$ and $\mathrm{HCA}_{2}$ are present in humans and rodents, whereas $\mathrm{HCA}_{3}$ is probably the result of a recent gene duplication of the $\mathrm{HCA}_{2}$ receptor and is only present in primates. All three receptors are particularly highly expressed in adipocytes, where they are thought to couple to $G_{i}$ proteins to cause antilipolytic effects. This has led to the development of a number of synthetic agonists, albeit of comparatively low affinity, that induce antidyslipidemic effects similar to those of nicotinic acid, the original surrogate ligand for $\mathrm{HCA}_{2}$. However, recently Lauring et al. (2012) found that synthetic agonists of $\mathrm{HCA}_{2}$ receptor do not fully mimic the lipid effects of nicotinic acid. Other pharmacological tools are limited. There are currently no selective antagonists or allosteric modulators for any of these receptors.

2. Lysophosphatidic Acid Receptors: LPA (GPR23), $L P A_{5}$ (GPR92), and $L P A_{6}$ (P2Y5). Lysophosphatidic acid (LPA; IUPHAR-DB ID no. 2906) is a membrane-derived lipid, which mediates its actions via a cluster of three structurally related GPCRs, $\mathrm{LPA}_{1-3}$. These receptors mediate a wide range of physiologic actions. Recently, two structurally dissimilar receptors, previously designated as orphans, have been added to the LPA receptor family. They bind LPA with high affinity (Chun et al., 2010), despite having closer sequence similarity to P2Y receptors. This suggests evolution of LPA responsiveness via two lineages. GPR23 (also known as P2Y9 and P2Y5-like) is activated by LPA (IUPHAR-DB ID no. 2906) (Noguchi et al., 2003) and has been classified as $\mathrm{LPA}_{4}$. The receptor is present in humans, rats, and mice and, interestingly, is located on the $\mathrm{X}$ chromosome in each species. The receptor is reported to couple to multiple $G$ proteins $\left(\mathrm{G}_{12 / 13}, \mathrm{G}_{\mathrm{q} / 11}, \mathrm{G}_{\mathrm{i}}\right.$, and $\left.\mathrm{G}_{\mathrm{s}}\right)$. Agonists and antagonists selective for $\mathrm{LPA}_{4}$ over other LPA receptors have not been developed. One group reported that $\mathrm{LPA}_{4}$ receptordeficient mice displayed no overt abnormalities but that $\mathrm{LPA}_{4}$-deficient mouse embryonic fibroblasts were hypersensitive to LPA-induced cell migration, suggesting that the receptor is a suppressor of LPA-dependent cell migration and invasion (Lee et al., 2008b). A second group (Sumida et al., 2010) showed that a subset of $\mathrm{LPA}_{4}$ deficient embryos did not survive gestation and displayed hemorrhages and/or edema in many organs, concluding that $\mathrm{LPA}_{4}$ regulates establishment of the structure and function of blood and lymphatic vessels during mouse embryogenesis.

The orphan receptor GPR92 has been classified as $\mathrm{LPA}_{5}$, which is activated by LPA (IUPHAR-DB ID no. 2906) (Kotarsky et al., 2006; Lee et al., 2006). Agonists and antagonists selective for $\mathrm{LPA}_{5}$ over other LPA receptors have not been developed, although there appears a preference for ether LPA analogs over ester LPA analogs (Williams et al., 2009) and targeted disruption of the $\mathrm{LPA}_{5}$ gene causes a pain phenotype (Lin et al., 2012).

The gene initially termed $6 H 1$ (Kaplan et al., 1993) was subsequently renamed P2RY5 due to sequence homology with P2Y receptors (Webb et al., 1996). LPA (IUPHAR-DB ID no. 2906) was proposed as a ligand for P2Y5 (Pasternack et al., 2008; Yanagida et al., 2009). Pasternack et al. (2008) identified homozygous truncating mutations in the P2RY5 (now LPAR6) gene and found the receptor to be essential for the maintenance of human hair growth. We recommend P2Y5 be classified as $\mathrm{LPA}_{6}$.

3. FFA4 (GPR120) and Omega-3 Fatty Acids. FFAs are essential nutritional components and, in addition, activate a family of three GPCRs (FFA1FFA3), which play critical roles in physiology and pathophysiology, particularly in metabolic disorders. GPR120 is abundantly expressed in intestine and functions as a receptor for saturated and unsaturated long-chain FFAs including palmitoleic acid, $\alpha$-linolenic acid (IUPHAR-DB ID no. 1049), and docosahexaenoic acid (IUPHAR-DB ID no. 1051) linked to the $\mathrm{G}_{\mathrm{q} / 11}$ pathway (Hirasawa et al., 2005). The authors showed that the main physiologic action of GPR120 by FFAs was the secretion of glucagon-like peptide-1 (GLP-1) in vitro and in vivo and an increase in circulating insulin. This has important therapeutic implications, as GLP-1 is the most potent insulinotropic incretin.

GPR120-deficient mice fed high-fat diets developed obesity, glucose intolerance, and fatty liver with decreased adipocyte differentiation and lipogenesis and enhanced hepatic lipogenesis. Conversely, in humans, GPR120 expression in adipose tissue is significantly higher in obese individuals than in lean controls, owing to a deleterious nonsynonymous mutation that inhibits GPR120 signaling activity. Furthermore, this variant increased the risk of obesity in European populations. The authors of this study (Ichimura et al., 2012) concluded that these studies show that dysfunction of GPR120 leads to obesity in both mouse and man. However, further studies are required to understand these apparently contradictory results.

GPR120 knockout mice (as well as FFA1 receptor knockout mice) showed a diminished taste preference for linoleic acid and oleic acid and diminished neurophysiological responses to several fatty acids, showing that FFA 1 and GPR 120 mediate the taste of fatty acids (Cartoni et al., 2010). We recommend GPR120 be classified as FFA4.

4. The Chemerin Receptor (Chemokine-like Receptor; CMKLR1; ChemR23) and Chemerin. Wittamer et al. (2003) first identified chemerin (IUPHAR-DB ID no. 2945), a potent $14-\mathrm{kDa}$ chemoattractant protein of a novel class, in biological fluids as the product of the human tazarotene-induced gene-2 (Tig-2; current gene symbol, RARRES2). It is secreted in the plasma as a 
precursor of low biologic activity, which upon proteolytic cleavage of its $\mathrm{COOH}$-terminal domain is converted to an agonist of CMKLR1 (Luangsay et al., 2009), the chemerin receptor. The pairing was confirmed by Meder et al. (2003) and Zabel et al. (2005). Chemerin, acting via this receptor, induces the migration of macrophages and dendritic cells in vitro, suggesting a proinflammatory role, whereas in vivo studies using chemerin receptordeficient mice suggest an anti-inflammatory action (Luangsay et al., 2009). Responses to chemerin that are abolished in receptor knockout mice include migration of dendritic cells and macrophages (Luangsay et al., 2009; Bondue et al., 2011a), adhesion of peritoneal exudate cells to fibronectin (Hart and Greaves, 2010), and enhancement of microbial particle clearance and apoptotic neutrophil ingestion by macrophages (Cash et al., 2010). Chemerin/CMKLR1 interaction also promotes adipogenesis and angiogenesis (for review, see Yoshimura and Oppenheim, 2011). We recommend CMKLR1 be classified as the chemerin receptor.

Resolvins are a family of potent lipid mediators derived from both eicosapentaenoic acid (IUPHAR-DB ID no. 3362) and docosahexaenoic acid (IUPHAR-DB ID no. 1051) (see Uddin and Levy, 2011). Resolvin E1 (IUPHAR-DB ID no. 3333), a potent anti-inflammatory and proresolving mediator derived from eicosapentaenoic acid generated during the resolution phase of inflammation, has also been reported as a ligand for the chemerin receptor (Arita et al., 2007). To date, this pairing has not been confirmed, and another group has failed to reproduce the activity of resolvin E1 on the chemerin receptor in binding and a range of functional assays (Bondue et al., 2011b).

5. CXCR7 (CMKOR1) with CXCL12 (SDF-1) and CXCL11 (ITAC). The chemokines stromal cell-derived factor-1 (SDF-1), also known as chemokine (C-X-C motif) ligand 12 (CXCL12), and interferon-inducible T-cell $\alpha$ chemoattractant (ITAC), also known as CXCL11, bind with high affinity to $C X C R 7$ and promote cell migration (Balabanian et al., 2005; Burns et al., 2006). CXCR7 does not signal through classic $\mathrm{G}$ protein-coupled mechanisms and has been proposed to function as a nonsignaling receptor that either mediates CXCL12 internalization and degradation or forms heterodimers with $C X C R 4$ to modify CXCR4 downstream signaling (Zhu and Murakami, 2012). However, there is now convincing evidence that CXCR7 is a functional receptor, signaling through $\beta$-arrestin to activate mitogen-activated protein kinases (Rajagopal et al., 2010; Zhu and Murakami, 2012). Intriguingly, in zebrafish, $C X C R 7$ has been shown to shape gradients of CXCL12 for optimal signaling at CXCR4 to mediate gonadal germ cell migration (Boldajipour et al., 2008). The phenotype of CXCR7deficient mice included postnatal lethality and cardiovascular defects (Sierro et al., 2007; Gerrits et al., 2008).

6. Succinate Receptor (SUCNR1 GPR91) with Succinate; Oxoglutarate Receptor (OXGR1 GPR99) with
2-Oxoglutarate ( $\alpha$-Ketoglutarate). Succinate (IUPHAR-DB ID no. 3637) and 2-oxoglutarate ( $\alpha$-ketoglutaric acid; IUPHAR-DB ID no. 3636) are intermediates of the citric acid cycle present at micromolar concentrations in blood and are regulated by respiration, metabolism, and renal mechanisms. He et al. (2004) proposed that SUCNR1 (GPR91) functions as a receptor for succinate, with an $\mathrm{EC}_{50}$ of $56 \mu \mathrm{M}$ in an aequorin assay, coupling to a pertussis toxin-sensitive $G_{i} / G_{0}$ and pertussis toxininsensitive $G_{q}$ pathways. They also proposed another closely related GPCR, OXGR1 (GPR99), to be activated by 2-oxoglutarate, with an $\mathrm{EC}_{50}$ of $70 \mu \mathrm{M}$ via a $\mathrm{G}_{\mathrm{q}}$-mediated pathway. Both pairings have been replicated in a $\beta$-arrestin assay (Southern et al., 2013), also at high $\mathrm{EC}_{50}$ values of $800 \mu \mathrm{M}$ for succinate binding to SUCNR1 and $130 \mu \mathrm{M}$ for 2-oxoglutarate binding to OXGR1. In Gpr91 knockout mice, there was an impairment in renin release from the kidney in response to high glucose levels, thought to be mediated by a paracrine signaling pathway involving accumulation of succinate and activation of GPR91 (Toma et al., 2008). Consistent with this, succinate increased blood pressure in rats and mice-an effect abolished in Gpr91-deficient mice (He et al., 2004). We recommend SUCNR1 be classified as the succinate receptor, and OXGR1 be classified as the oxoglutarate receptor.

\section{B. Class B}

No recommendations.

\section{Class $C$}

No recommendations.

\section{Pairings of Orphan Receptors with Cognate Ligands Reported by a Single Paper or Where a Formal Pairing Is Yet To Be Agreed}

The following is a list of 32 receptors for which single publications have claimed to identify the endogenous ligand; alternatively, input from the scientific community is needed to reproduce and validate these findings. The minimum criterion for NC-IUPHAR to recommend that an orphan receptor receives official recognition is that the pairing of the ligand with the receptor should be repeated by at least one independent laboratory, with no overlap between the researchers, ideally by a different assay. The majority of papers discussed below have used artificially expressed receptors linked to a reporter system; the density of receptors per cell can be substantially higher than in native tissues with the potential for false positives.

\section{A. Class A}

1. GPR 1 and Chemerin. On the basis of its homology to CMKLR1, Barnea et al. (2008) identified chemerin (IUPHAR-DB ID no. 2945) as a GPR1 ligand using a $\beta$-arrestin assay. An iodinated C-terminal peptide 
fragment of chemerin (149-157 amino acids of full-length chemerin; chemerin C-terminal peptide; IUPHAR-DB ID no. 3422) bound to GPR1-transfected cells with a single binding site $\left(K_{\mathrm{d}}\right.$ of $\left.5.3 \mathrm{nM}\right)$, similar to the $K_{\mathrm{d}}$ of $4.9 \mathrm{nM}$ for CMKLR1-transfected cells. However, in a $\beta$-arrestin recruitment assay, chemerin had an $\mathrm{EC}_{50}$ of $240 \mathrm{pM}$ at GPR1 compared with $3 \mathrm{nM}$ for $C M K L R 1$. A C-terminal peptide fragment, chemerin 145-157, also bound to GPR1 in a $\beta$-arrestin assay (Southern et al., 2013). Chemerin also binds to CCRL2 (see below; Leick et al., 2010), which is thought to be a nonsignaling receptor that functions to reduce the local concentration of the molecule (Zabel et al., 2008).

2. GPR3/GPR6/GPR12 and Sphingosine 1-Phosphate. Currently, there are five lysophospholipid receptors, which have been classified as $\mathrm{S}_{1} \mathrm{P}_{1}-\mathrm{S}_{1} \mathrm{P}_{5}$ receptors because their endogenous ligand is accepted to be the lysophospholipid sphingosine 1-phosphate (S1P; IUPHAR-DB ID no. 911). GPR3, GPR6, and GPR12 are phylogenetically related to the S1P, LPA, and melanocortin receptors (Gloriam et al., 2007). They were proposed to be three additional S1P receptors following screening of 200 bioactive lipids (Uhlenbrock et al., 2002 ), but this result was not replicated in a $\beta$-arrestinbased assays by two different groups (Yin et al., 2009, Southern et al., 2013). S1P was also suggested to be a high-affinity ligand for GPR6 in a study by Ignatov et al. (2006). All three receptors display significant constitutive activation of adenylate cyclase (through $\mathrm{G}_{\mathrm{s}}$ ) and calcium mobilization (through $\mathrm{G}_{\mathrm{i}}$ ), which can be modulated by S1P and dihydrosphingosine 1-phosphate (IUPHAR-DB ID no. 2921) with nanomolar $\mathrm{EC}_{50}$ values.

3. GPR4/GPR65/GPR68/GPR132 (G2A) and Protons. In biological systems, carbon dioxide exists in equilibrium with bicarbonate and protons $\left(\mathrm{H}^{+}\right)$, which must be sensed to be able to maintain cellular $\mathrm{pH}$. The cluster of structurally related GPCR genes encoding GPR4 (Ludwig et al., 2003; Tobo et al., 2007), GPR65 (Wang et al., 2004), GPR68 (Ludwig et al., 2003), and GPR132 (Murakami et al., 2004) have been proposed to function as proton-sensing receptors detecting acidic $\mathrm{pH}$ (Seuwen et al., 2006). This family was originally reported to respond to lipids such as sphingosylphosphorylcholine, lysophosphatidylcholine, and psychosine, but these reports have been retracted (Zhu et al., 2001; Witte et al., 2005) and others have found negative regulation of these receptors by high micromolar concentrations of lipids not to be specific (Seuwen et al., 2006). The current balance of opinion is in favor of proton sensing. The physiologic role of this family in sensing $\mathrm{pH}$ is beginning to emerge (Kostenis, 2004; Meyer zu Heringdorf and Jakobs, 2007). Yang et al. (2007) reported that deletion of the GPR4 gene in mice leads to partially penetrant vascular abnormalities during development and speculated that the receptor functions in blood vessel $\mathrm{pH}$ sensing. Gene disruption of GPR4 is also associated with reduced sensitivity to vascular endothelial growth factor-evoked angiogenesis (Wyder et al., 2011).

4. GPR17: Dual Receptor for Cysteinyl Leukotrienes / Nucleotides. GPR17 is phylogenetically related to the nucleotide (P2Y) and cysteinyl leukotriene (CysLT) receptors (Gloriam et al., 2007) and may provide an ancestral link to the two families. Both CysLTs (with $\mathrm{EC}_{50}$ values in the nanomolar range) and uracil nucleotides $\left(\mathrm{EC}_{50}\right.$ in the micromolar range) have been reported to activate $G P R 17$, leading to both adenylyl cyclase inhibition and intracellular calcium increases (Ciana et al., 2006). Benned-Jensen and Rosenkilde (2010) confirmed the activation of GPR17 by uracil nucleotides but were unable to demonstrate activation or binding by CysLTs. A third group (Maekawa et al., 2009) was not able to demonstrate activation of GPR17 by either UDP-glucose or CysLTs and instead proposed that GPR17 functions as a negative regulator of the CysLT $_{1}$ receptor response to leukotriene $\mathrm{D}_{4}$. In vivo inhibition of GPR17 or in vivo knockdown by antisense molecules reduced ischemic damage in a rat focal ischemia model, suggesting that GPR17 may be a target mediating brain damage by nucleotides and CysLTs (Ciana et al., 2006).

5. GPR18 and N-Arachidonoylglycine, Cannabinoid Ligands. Kohno et al. (2006) screened a lipid library and identified an endogenous ligand, $N$-arachidonoylglycine (NAGly; IUPHAR-DB ID no. 3635) by measuring an increase in intracellular $\mathrm{Ca}^{2+}$ concentration in GPR18-transfected cells. NAGly also inhibited forskolininduced cAMP production in a pertussis toxin-sensitive manner in the GPR18-transfected $\mathrm{CHO}$ cells, with an $\mathrm{EC}_{50}$ value of $20 \mathrm{nM}$. GPR18 is mainly expressed in lymphoid cell lines, such as spleen and thymus, with moderate expression in brain, testis, ovary, and lung, and the authors suggested that GPR18 might be involved in regulation of the immune system. NAGly has been suggested to be an endogenous metabolite of the endocannabinoid anandamide ( $N$-arachidonoyl ethanolamine; IUPHAR-DB ID no. 2364), differing only in a change in the oxidation state of the carbon $\beta$ to the amido nitrogen that greatly reduces agonist activity at cannabinoid receptors $\mathrm{CB}_{1}$ and $\mathrm{CB}_{2}$. NAGly is present in a range of tissues including skin, small intestine, kidney, and testis and displays distinct antinociceptive and antiinflammatory activities. McHugh et al. (2010) have suggested that NAGly mediates these actions via a putative "abnormal cannabidiol" receptor, which is GPR18. More recently, GPR18 has been confirmed to respond to NAGly (McHugh et al., 2012) but also to the prototypic $\mathrm{CB}_{1}$ and $\mathrm{CB}_{2}$ cannabinoid receptor ligand, $\Delta^{9}$-tetrahydrocannabinol (IUPHAR-DB ID no. 2424). In contrast, the pairing of NAGly and $\Delta^{9}$-tetrahydrocannabinol could not be repeated in a $\beta$-arrestin assay (Southern et al., 2013). The nomenclature of GPR18 is currently being considered by the cannabinoid receptor subcommittee of NC-IUPHAR. 
6. GPR31 and 12-(S)-Hydroxyeicosatetraenoic Acid. 12-(S)-Hydroxyeicosatetraenoic acid [12-(S)-HETE; IUPHAR-DB ID no. 3404] is a 12-lipoxygenase metabolite of arachidonic acid (IUPHAR-DB ID no. 2391), which produces a number of cellular responses including cytoskeletal remodeling to facilitate cell chemotaxis and secretion of proteinases and vascular endothelial growth factor leading to an angiogenic response. 12-(S)-HETE treatment of cancer cells also enhanced the expression of integrins and fibronectin, which prolong cell survival. GPR31 displayed highaffinity binding for tritiated $12-(S)$-HETE $\left(K_{\mathrm{d}}=5 \mathrm{nM}\right)$, and unlabeled 12-(S)-HETE stimulated guanosine $5^{\prime}-3$ $O$-(thio)triphosphate coupling in the membranes of GPR31-transfected cells, with an $\mathrm{EC}_{50}$ of $0.28 \mathrm{nM}$ (Guo et al., 2011). In concordance, GPR31 is phylogenetically closest to the OXE receptor (for which the ligand is 5-oxo-6,8,11,14-eicosatetraenoic acid; IUPHAR-DB ID no. 3391) (Gloriam et al., 2007).

7. GPR32 and Resolvin D1. By use of a $\beta$-arrestin assay, Krishnamoorthy et al. (2010) demonstrated that resolvin D1 (RvD1; IUPHAR-DB ID no. 3934), which is produced physiologically from the oxidation of docosahexaenoic acid (IUPHAR-DB ID no. 1051), had a remarkably high $\mathrm{EC}_{50}$ value of $4 \mathrm{pM}$. The aspirintriggered epimer of RvD1 (AT-RvD1) and stable synthetic analogs $17(R / S)$-methyl RvD1 and RvD1ME were equally potent. These compounds also stimulated $\beta$-arrestin binding in cells expressing recombinant human formyl peptide receptors $A L X / F P R 2$ (ALX/ FPR2 is also considered a lipoxin $\mathrm{A}_{4}$ receptor and thought to bind peptides and two classes of lipids, the lipoxins and resolvins). Krishnamoorthy et al. (2012) suggest that RvD1 mediates the resolution of acute inflammation by interaction with these two receptors. Resolvin D5 has been reported to activate GPR32 by Chiang et al. (2012). In contrast, the pairing of RvD1 with GPR32 could not be repeated in a recent $\beta$-arrestin assay (Southern et al., 2013).

8. GPR34 and Lysophosphatidylserine. GPR34 is phylogenetically related to the P2Y receptor family (Gloriam et al., 2007). Lysophosphatidylserine (LysoPS; IUPHAR-DB ID no. 4064) is thought to function as an immunologic regulator as it augments the degranulation of peritoneal mast cells where GPR34 is abundantly expressed. LysoPS caused a pertussis toxin-sensitive decrease in the cAMP level of $\mathrm{CHO}$ cells expressing GPR34, with an $\mathrm{EC}_{50}$ value of $270 \mathrm{nM}$. These cells did not respond to structurally related phospholipids examined, including lysophosphatidylethanolamine, lysophosphatidylcholine, LPA, S1P, and phosphatidylserine (Sugo et al., 2006). LysoPS has also been reported as the activating ligand by others (Iwashita et al., 2009; Kitamura et al., 2012), with the suggestion that the receptor prefers fatty acid substitution in the $s n-2$ position (Kitamura et al., 2012). In contrast, in a detailed phylogenetic study, Ritscher et al. (2012) concluded that LysoPS had no or very weak agonistic activity at most vertebrate GPR34 orthologs investigated and that the search for the endogenous agonist should consider additional chemical entities.

9. GPR35 and Kynurenic Acid/2-Acyl Lysophosphatidic Acid. Wang et al. (2006a) first reported that kynurenic acid (IUPHAR-DB ID no. 2918) was an agonist of GPR35; this observation has since been replicated in functional assays releasing interleukin 4 (Fallarini et al., 2010 ) and in a $\beta$-arrestin assay (Southern et al., 2013), but controversy remains whether the endogenous ligand reaches sufficient tissue concentrations to activate the receptor (Kuc et al., 2008). 2-Acyl lysophosphatidic acid (2-oleoyl-LPA; IUPHAR-DB ID no. 2936) has also been proposed as an endogenous ligand (Oka et al., 2010b). Zaprinast (IUPHAR-DB ID no. 2919), a cyclic GMPselective phosphodiesterase (PDE5A/PDE6) inhibitor, is reported to be an agonist for GPR35 (Taniguchi et al., 2006). GPR35 is also activated by the loop diuretic drugs bumetanide (IUPHAR-DB ID no. 4837) and furosemide (frusemide; IUPHAR-DB ID no. 4839) (Yang et al., 2012), the pharmaceutical adjunct pamoic acid (IUPHAR-DB ID no. 2920) (Neubig, 2010; Zhao et al., 2010), gallic acid, wedelolactone (Deng et al., 2012), D-luciferin (Hu et al., 2012), and multiple metabolites of tyrosine (IUPHAR-DB ID no. 4791) (Deng et al., 2012), but it is unclear whether these compounds are selective for this receptor.

10. GPR37 and Neuropeptide Head Activator. The neuropeptide head activator (IUPHAR-DB ID no. 2496), originally isolated from the freshwater coelenterate hydra (Hydra attenuata), is a mitogen for all types of cells in Hydra as well as mammalian cell lines of neuronal or neuroendocrine origin. Electrophysiological recordings in frog oocytes and in mammalian cell lines as well as $\mathrm{Ca}^{2+}$ mobilization assays revealed nanomolar affinities $\left(\mathrm{EC}_{50}\right.$ value of $\left.3 \mathrm{nM}\right)$ for activation of GPR37. An inhibitory G protein-mediated signal transduction and treatment with head activator resulted in internalization of GPR37. Overexpression of GPR37 led to aggregate formation, retention of the receptor in the cytoplasm, and low survival rates of transfected cells, leading to the suggestion that misfolded GPR37 contributes to the cell death that can be detected in conditions such as Parkinson's disease (Rezgaoui et al., 2006).

GPR37 has been reported to associate with and regulate the dopamine transporter, while gene disruption results in altered striatal signaling (Marazziti et al., 2007, 2011). Although the isolation of a peptide of identical amino acid sequence to Hydra head activator from human hypothalamus, bovine hypothalamus, and rat intestine has been reported (Bodenmuller and Schaller, 1981), its existence in mammals is unclear because there is currently no evidence for the presence of a precursor gene for this peptide in any sequenced genome. However, it is possible that the precursor protein may lie within an unsequenced part of the genome. Interestingly, GPR37 overexpression in 
HEK cells can induce cellular autophagy, which may prevent the selective degeneration of GPR37-expressing neurons, as reported for Parkinson's and related neurodegenerative diseases (Marazziti et al., 2009). The pairing of GPR37 with neuropeptide head activator could not be replicated in a recent $\beta$-arrestin assay (Southern et al., 2013).

11. GPR39 and $\mathrm{Zn}^{2+}$ but Retraction of Obestatin as Cognate Ligand. The initial reported pairing of GPR39 with the novel peptide obestatin (IUPHAR-DB ID no. 5336), derived from the precursor of the appetitestimulating hormone ghrelin (Zhang et al., 2005), could not be repeated; $\left[{ }^{125} \mathrm{I}\right]$ Obestatin did not bind GPR39, and obestatin was without action on GPR39-transfected cells in various functional assays (cAMP production, calcium mobilization, and GPR39 internalization) (Lauwers et al., 2006; Chartrel et al., 2007; Holst et al., 2007; Tremblay et al., 2007). Zhang et al. (2007) have since confirmed that they could not reproduce their findings on obestatin binding and activation of GPR39 receptors in vitro. The results they originally obtained may have been caused by contamination of the sample of obestatin by impurities and loss of binding by the labeled analog as a result of labeling with iodine. The authors are to be commended for publishing the reasons for being unable to repeat their original study. $\mathrm{Zn}^{2+}$ ions have since been proposed as the cognate ligand (Holst et al., 2007; Yasuda et al., 2007; Sharir et al., 2010; Popovics and Stewart, 2011). There are conflicting reports concerning the effects of disruption of GPR39 on body weight (Moechars et al., 2006; Tremblay et al., 2007). The receptor is expressed in pancreatic $\beta$ cells, and there is evidence for a role of GPR39 in the regulation of glucose homeostasis (Petersen et al., 2011).

As described above, a significant number of pairings of GPCRs with putative endogenous ligands are currently supported by a single paper and await independent confirmation by other groups. A number of pairings have been formally retracted. For example, the reported pairing of GPR39 by obestatin (IUPHAR-DB ID no. 5336) (Zhang et al., 2005) could not be repeated in various in vitro assays (Chartrel et al., 2007). Nevertheless, more than 50 papers have subsequently described the physiologic and pharmacological actions of the peptide, including acting as an anorectic hormone, decreasing food intake, reducing body weight gain, regulating sleep, and affecting cell proliferation. To date, no alternative receptor or transducing mechanism has been identified.

12. GPR55 and Lysophosphatidylinositol. GPR55 was identified as an orphan GPCR abundantly expressed in human caudate nucleus and putamen but not in hippocampus, cerebellum, frontal cortex, or liver (Sawzdargo et al., 1999). A number of reviews have highlighted the confusion arising from studies investigating the pharmacology of GPR55 (Godlewski et al., 2009; Ross, 2009, 2011; Pertwee et al., 2010; Sharir and Abood, 2010). It is unclear why there are discrepancies between different laboratories, although it may be that the use of distinct host cells with distinct repertoires of potential signaling partners and the analysis of distinct signaling pathways may contribute to the variation in agonist profiles. From these studies, however, a certain level of consensus has been attained identifying lysophosphatidylinositol (LPI; IUPHAR-DB ID no. 4028) as an endogenous agonist (Oka et al., 2007). The activation of GPR 55 by LPI has been described by numerous groups (Lauckner et al., 2008; Waldeck-Weiermair et al., 2008; Henstridge et al., 2009, 2010; Kapur et al., 2009; Whyte et al., 2009; Yin et al., 2009; Bondarenko et al., 2010; Ford et al., 2010; Oka et al., 2010a; Ishiguro et al., 2011; Pineiro et al., 2011; Southern et al., 2013). Commercially available LPI is primarily plant-derived, containing mixtures of fatty acid substituents with a majority of mediumchain saturated and monounsaturated fatty acids at the 1-position of LPI (Oka et al., 2009). It has been suggested that a 2-isomer of LPI, 2-arachidonoyl-sn-glycero-3phosphoinositol (arachidonoyl LPI; IUPHAR-DB ID no. 4029), present at levels similar to the endogenous cannabinoid 2-arachidonoylglycerol (IUPHAR-DB ID no. 729) (Sugiura et al., 1995; Artmann et al., 2008; Oka et al., 2009), is a more realistic candidate for an endogenous GPR55 ligand (Oka et al., 2009). The biologic activity of 2-arachidonoyl LPI was markedly higher than those of other molecular species of LPI tested as activators of extracellular signal-regulated kinase (ERK) or elevation of intracellular calcium ions in heterologous expression studies of GPR55 (Oka et al., 2009). It should be noted, however, that LPI has actions independent of GPR55, in inhibiting the plasma membrane $\mathrm{Na}^{+} / \mathrm{K}^{+}$-ATPase (Bondarenko et al., 2010) and regulating endothelial cell $\mathrm{BK}_{\mathrm{Ca}}$ channels, allowing an enhancement of activity at times when the channel activity was low and reducing channel activity at higher levels of channel stimulation (Bondarenko et al., 2010). The nomenclature of GPR55 is currently under consideration by the cannabinoid receptor subcommittee of NC-IUPHAR.

13. GPR75 and CCL5 (RANTES). A single paper reports that the chemokine CCL5 (RANTES; IUPHAR-DB ID no. 758) stimulates $\mathrm{Ca}^{2+}$ mobilization and inositol trisphosphate formation in cells transfected with GPR75 (Ignatov et al., 2006). However, the pairing of CCL5 and GPR75 could not be repeated in a recent $\beta$-arrestin assay (Southern et al., 2013).

14. GPR84 and Medium-Chain FFAs. A single paper has reported the pairing of medium-chain FFAs with carbon chain lengths of 9-14 with GPR84 (Wang et al., 2006b). Medium-chain FFAs mediated calcium mobilization, inhibited cAMP production, and stimulated $\left[{ }^{35} \mathrm{~S}\right]$ GTP binding via a pertussis toxin-sensitive $\mathrm{G}_{\mathrm{i} / \mathrm{o}}$ pathway. GPR84 is expressed in leukocytes and induced in monocytes/macrophages upon activation by lipopolysaccharide, stimulating proinflammatory cytokines, suggesting that GPR84 may link fatty acid metabolism to 
immunologic regulation (Wang et al., 2006b). GPR84 is highly expressed in the bone marrow, and $\mathrm{T}$ cells from GPR84 knockout mice displayed augmented interleukin4 production in response to stimulation with anti-CD3, suggesting a role for GPR84 in regulating early interleukin-4 gene expression in activated $\mathrm{T}$ cells (Venkataraman and Kuo, 2005). Currently there is insufficient evidence to recommend that GPR84 be classified as FFA5.

15. GPR87 and LPA. A single paper reports that in CHO cells stably expressing GPR87 fused with $\mathrm{G} \alpha_{16}$ protein, LPA (IUPHAR-DB ID no. 2906) induced transient increases in intracellular $\mathrm{Ca}^{2+}$, with a low $\mathrm{EC}_{50}$ value of $40 \mathrm{nM}$. Calcium increases were blocked by LPA receptor antagonists and by RNA silencing of GPR87. GPR87 was shown to be more closely related to the P2Y and P2Y-related receptors than to LPA receptors (Nonaka et al., 2005), but none of the nucleotides or their derivatives activated GPR87 (Tabata et al., 2007).

16. GPR119 and Derivatives of Oleate. GPR119 is expressed in pancreatic $\beta$ cells and the gastrointestinal tract and appears to be activated by multiple derivatives of the medium-chain monounsaturated fatty acid oleate (IUPHAR-DB ID no. 1054), including lysophosphatidylcholine (IUPHAR-DB ID no. 2508) (Soga et al., 2005), $N$-oleoylethanolamine (IUPHAR-DB ID no. 2661) (Overton et al., 2006, Ning et al., 2008; Southern et al., 2013), $N$-oleoyldopamine (Chu et al., 2010), and 2oleoylglycerol (IUPHAR-DB ID no. 5112) (Hansen et al., 2011).

When fed a low-fat diet, GPR119 knockout mice had normal plasma glucose and lipids but lower body weights and lower postprandial levels of GLP-1. Nutrientstimulated GLP-1 release was attenuated (Lan et al., 2009). GPR119 has evolved into a potential target for the next generation of compounds to treat type 2 diabetes mellitus, with numerous publications describing synthetic ligands, some of which are commercially available. Both the preclinical and clinical data suggest that GPR119 agonists will be promising antidiabetic drugs (Shah and Kowalski, 2010). The nomenclature of GPR119 is currently being considered by the cannabinoid receptor subcommittee of NC-IUPHAR.

17. GPR182 and Adrenomedullin. Kapas et al. (1995) reported that GPR182 was a receptor for adrenomedullin (IUPHAR-DB IDs nos. 683, 697, 3589), but Kennedy et al. (1998) failed to replicate this finding, and therefore, the endogenous ligand of this receptor remains unknown.

18. GPR183 (EBI2) and Oxysterols. Two independent reports (Hannedouche et al., 2011; Liu et al., 2011) have proposed oxysterols as ligands for GPR183. Liu et al. (2011) isolated oxysterols from porcine spleen extracts and demonstrated that $7 \alpha, 25$-dihydroxycholesterol $(7 \alpha, 25$-OHC; IUPHAR-DB ID no. 4350) was the most potent endogenous ligand of this receptor, with a $K_{\mathrm{d}}$ of $450 \mathrm{pM}$. $7 \alpha, 25-\mathrm{OHC}$ is synthesized from cholesterol by the sequential action of cholesterol 25-hydroxylase and CYP7B1 (25-hydroxycholesterol 7- $\alpha$-hydroxylase). Consistent with $7 \alpha, 25-\mathrm{OHC}$ as an endogenous ligand, inhibition of CYP7B1 with clotrimazole reduced the content of $7 \alpha, 25-\mathrm{OHC}$ in the mouse spleen and mimicked the phenotype of preactivated B cells from gpr183deficient mice (Liu et al., 2011), and mice deficient in cholesterol 25-hydroxylase had a similar phenotype to GPR183 knockout mice (Hannedouche et al., 2011). Oxysterols can affect immune and inflammatory responses as well as cholesterol metabolism, and these effects are normally thought to be by via nuclear hormone receptors rather than a GPCR.

19. P2Y10 and S1P/LPA. The gene encoding P2Y10 (P2RY10) was originally named on the basis of sequence similarity to other $\mathrm{P} 2 \mathrm{Y}$ receptors, but subsequent phylogenetic analyses have shown that $P 2 Y 10$ is most closely related in sequence to receptors for plateletactivating factor (IUPHAR-DB ID no. 1831) and LPA (IUPHAR-DB ID no. 2906) (Gloriam et al., 2007). S1P (IUPHAR-DB ID no. 911) and LPA stimulated increases in intracellular $\mathrm{Ca}^{2+}$ in CHO cells stably expressing P2Y10 fused with a $\mathrm{G} \alpha_{16}$ protein, with $\mathrm{EC}_{50}$ values of 53 and $130 \mathrm{nM}$, respectively (Murakami et al., 2008). These responses were blocked by S1P and LPA receptor antagonists and by RNA silencing of P2Y10 in these cells. In mice, $P 2 Y 10$ was widely expressed, including in reproductive organs, brain, lung, and skeletal muscle. The authors concluded that P2Y10 is a dual lysophospholipid receptor, but it has not yet been accepted as an LPA receptor by NC-IUPHAR.

20. MAS1 and Angiotensin-(1-7). Angiotensin-converting enzyme 2 metabolizes angiotensin II (IUPHAR-DB ID no. 2504) to angiotensin-(1-7) [Ang-(1-7), IUPHAR-DB ID no. 582], which functions as a vasodilator and antiproliferative agent. Santos et al. (2003) first provided evidence that some of the actions of Ang-(1-7) are mediated via the MAS1 receptor. Ang-(1-7) bound to MAS1-transfected cells and elicited arachidonic acid (IUPHAR-DB ID no. 2391) release. Deletion of the Mas1 gene in mice abolished the binding of Ang-(1-7) in mouse kidney and abolished the antidiuretic action of the peptide after an acute water load (Santos et al., 2003). Mas1-deficient mouse aortas lost Ang-(1-7)-induced relaxation responses. For further information on the effect of deleting the MAS1 receptor, see Alenina et al. (2008).

21. LGR4, LGR5, and LGR6 and R-Spondins. $L G R 4, L G R 5$, and LGR6 were first identified as a family of structurally distinct seven-transmembrane receptors with homology to glycoprotein hormone receptors (Hsu et al., 1998, 2000). R-spondins (IUPHAR-DB ID nos. $3697,3698,3699,3700,4383)$ are a group of secreted proteins that enhance $\mathrm{Wnt} / \beta$-catenin signaling, which plays essential roles in embryonic development and in the self-renewal and maintenance of adult stem cells. Carmon et al. (2011) demonstrated that LGR4 and LGR5 bind the R-spondins with high affinity and mediate the potentiation of $\mathrm{Wnt} / \beta$-catenin signaling by enhancing the 
phosphorylation of the Wnt coreceptor LRP6. Gong et al. (2012) showed that LGR6 also binds and responds to $\mathrm{R}$-spondins, and de Lau et al. (2011) reported that each of the four R-spondins can bind to LGR4,LGR5, and LGR6. However, these receptors do not couple to $G$ proteins or to $\beta$-arrestin, suggesting that they do not function as conventional GPCRs (Gong et al., 2012). LGR5 is a marker of stem cells in the base of intestinal crypts and in hair follicles; significant data support $L G R 5^{+}$stem cells as cells of origin for colorectal carcinoma and also implicate LGR5 as a mediator of tumor aggression (Kleist et al., 2011).

22. Mas-Related GPCRs: MRGPRD with $\beta$-Alanine; MRGPRX1 with Bovine Adrenal Medulla Peptide 22 (BAM22); MRGPRX2 with Cortistatin-14. Of the eight human Mas-related GPCRs (MRGs), four (MRGPRD, $M R G P R E, M R G P R F$, and MRGPRG) have clear orthologs in rodents, whereas the cluster of genes including human MRGPRX1, MRGPRX2, MRGPRX3, and MRGPRX4 is found only in primates and is replaced in rodents with a family of genes ( $>25$ in mice; $\sim 10$ in rats) that have no obvious human counterparts (Dong et al., 2001). Certain rodent MRGs have been reported to respond to adenine (Bender et al., 2002) and to RF-amide peptides including neuropeptide FF (Han et al., 2002; Lee et al., 2008a), but the relevance of these findings to man is unclear. MRGs are expressed predominantly in small-diameter sensory neurons of the dorsal root ganglia, where there is emerging evidence that they may be mediators of histamine-independent itch (Liu et al., 2009; Wilson et al., 2011).

$\beta$-Alanine (IUPHAR-DB ID no. 2365) induced the rapid mobilization of intracellular $\mathrm{Ca}^{2+}$ in $\mathrm{CHO}$ cells expressing human, rat, or mouse MRGPRD (TGR7) in a concentration-dependent manner, with $\mathrm{EC}_{50}$ values of 15, 14, and $44 \mu \mathrm{M}$, respectively (Shinohara et al., 2004). Responses to $\beta$-alanine were pertussis toxin-sensitive (Shinohara et al., 2004; Crozier et al., 2007). $\beta$-Alanine activated MRGPRD in a $\beta$-arrestin assay with a similar $\mathrm{EC}_{50}$ value of $15 \mu \mathrm{M}$ (Southern et al., 2013). $\left[{ }^{3} \mathrm{H}\right] \beta$-Alanine bound to MRGPRD-expressing CHO cells, but compounds structurally related to $\beta$-alanine, including L-glycine (IUPHAR-DB ID no. 727), L-alanine (IUPHAR-DB ID no. 720), taurine (IUPHAR-DB ID no. 2379), and L-anserine, did not stimulate intracellular calcium. Milasta et al. (2006) also demonstrated that cells expressing $M R G P R D$ responded to $\beta$-alanine. There was evidence that responses to $\beta$-alanine (elevations of intracellular $\mathrm{Ca}^{2+}$, phosphorylation of mitogen-activated protein kinases ERK1 and ERK2, and receptor internalization) could be modulated by the formation of heterodimers with MRGPRE (Milasta et al., 2006).

Bovine adrenal medulla peptide 22 (BAM22) is a C-terminally extended form of Met-enkephalin produced by proteolytic cleavage of the opioid peptide precursor proenkephalin A. Lembo et al. (2002) found that BAM22 was the most potent compound evoking a concentration-dependent release of intracellular calcium in cells stably expressing the human MRGPRX1 (which they called sensory neuron-specific receptor 3 or SNSR3), with an $\mathrm{EC}_{50}$ value of $13 \mathrm{nM}$. Many of the classic opioid peptides were inactive at MRGPRX1, and classic opioid antagonists such as naloxone were inactive as antagonists. Chen and Ikeda (2004) and Solinski et al. (2010) confirmed that BAM22 is an agonist of $M R G P R X 1$, and this has been replicated in a $\beta$-arrestin assay (Southern et al., 2013). Chloroquine, an antimalarial drug that frequently produces itch as a side effect, activates MRGPRX1, consistent with a possible role for this receptor in mediating histamine-independent itch (Liu et al., 2009).

Robas et al. (2003) reported that cortistatin-14 (IUPHAR-DB ID no. 2007), a neuropeptide related to somatostatin but encoded by a different gene (de Lecea et al., 1996), stimulated intracellular calcium in cells expressing human MRGPRX2, with an $\mathrm{EC}_{50}$ of $25 \mathrm{nM}$. A number of other cyclic peptides showed high nanomolar potency. Kamohara et al. (2005) confirmed this pairing but also found that the endogenous peptides proadrenomedullin N-terminal 20 peptide (PAMP-20; IUPHAR-DB ID no. 4057) and its N-terminally truncated analog, PAMP-12 (IUPHAR-DB ID no. 4056), also activated the receptor with a similar potency in calcium mobilization. Cortistatin-14 was also shown to bind to MRGPRX2 in a $\beta$-arrestin assay (Southern et al., 2013).

MRGPRX2 coupled with $\mathrm{G}_{\mathrm{q}}$ and $\mathrm{G}_{\mathrm{i}}$. Nothacker et al. (2005) showed in structure-activity studies that both cortistatin and PAMP bind to and activate MRGPRX2 at the same binding site owing to a common internal structural motif that is centered around an octapeptide that alternates aromatic and basic amino acids, and both peptides were proposed as surrogate ligands for this receptor. Nonpeptide MRGPRX2 receptor agonists have been identified (Malik et al., 2009).

\section{B. Class B}

All of the orphans in this subfamily are called adhesion receptors in some classifications (see, for example, Lagerström and Schioth, 2008); a defining feature of this subfamily is the presence of a GPCR proteolytic sitecontaining stalk region. None of the following putative ligands has been demonstrated to signal through conventional $\mathrm{G}$ protein-coupled mechanisms (although see GPR56 below).

1. BAI1 and Phosphatidylserine. A single paper reports phosphatidylserine (IUPHAR-DB ID no. 3638) as a ligand for $B A I 1$, which has a role in the engulfment and subsequent degradation of apoptotic cells (Park et al., 2007; reviewed in Bratton and Henson, 2008).

2. BAI3 and C1q-like Proteins. C1q-like proteins are small, secreted proteins of unknown function that are synthesized from four genes in mammals, expressed almost exclusively in brain, and produced in differential patterns by specific types of neurons. According to one 
report, C1q-like proteins bind to the extracellular thrombospondin-repeat domain of BAI3 with high affinity and act, at least in part, to regulate synapse formation and/or maintenance (Bolliger et al., 2011).

3. CD97 and Decay Accelerating Factor. Several groups have reported that decay accelerating factor (CD55), a regulatory protein of the complement cascade, is a ligand of CD97 (Hamann et al., 1996; Qian et al., 1999; Lin et al., 2001). Thy-1 (CD90) has been reported to bind to CD97, and this interaction has been proposed to play a role in the regulation of leukocyte trafficking by facilitating adhesion of polymorphonuclear cells to activated endothelial cells (Wandel et al., 2012). Chondroitin sulfate has been reported to be a ligand of both CD97 and EMR2 (Stacey et al., 2003).

4. GPR56 and Collagen Type III. Collagen, type III, $\alpha-1$ (gene symbol, COL3A1) has been proposed as the ligand of GPR56 (Luo et al., 2011), signaling by activating RhoA through coupling to $\mathrm{G}_{12 / 13}$. Transglutaminase 2, a major crosslinking enzyme in the extracellular matrix, has also been proposed as a ligand of GPR56 (Xu and Hynes, 2007).

5. LPHN1 and LPHN3. The massive synaptic exocytosis caused by the black widow spider venom $\alpha$-latrotoxin is thought to be due to toxin binding to two distinct receptor families: the latrophilin group of class B GPCRs (LPHN1, -2, and -3) and the neurexins (neurexin$1,-2$, and -3 ), which are presynaptic membrane proteins. $L P H N 1$ has been proposed to be a ligand of neurexins, producing a stable intercellular adhesion complex (Boucard et al., 2012). Lasso, a splice variant of teneurin-2, a brain-specific orphan cell surface receptor with a function in neuronal pathfinding and synaptogenesis (Silva et al., 2011) and FLRT3, a member of the FLRT family of leucine-rich repeat transmembrane proteins (O'Sullivan et al., 2012), have been reported to be endogenous postsynaptic ligands for LPHN1 and LPHN3, respectively.

\section{Class $C$}

1. GPRC6A and Calcium, Amino Acids, and Osteocalcin. GPRC6A has been reported to sense both nutrientderived factors, such as calcium and amino acids (Christiansen et al., 2007; Pi et al., 2012); testosterone (Pi et al., 2010); and the bone-derived hormone osteocalcin (Oury et al., 2011; Pi et al., 2011).

\section{Orphan Receptors with Activity in Absence of an Endogenous Ligand, Activation by Surrogate Ligands, or Significant Phenotype in Genetically Modified Animals}

Although ligands for orphan GPCRs continue to be identified, there is also evidence that some may have functions in the absence of an endogenous transmitter through constitutive activity or by modulating the activity of other GPCRs via dimerization. These receptors may still represent a druggable target by the discovery of synthetic ("surrogate") ligands. Other seventransmembrane receptors may not signal via conventional pathways such as $G$ proteins but still function to modulate the actions of transmitters.

A. Constitutively Active GPCRs. Constitutive activity is defined by receptor signaling in the absence of a ligand and has mainly been detected using in vitro studies measuring downstream signaling, which may be reduced by the action of inverse agonists. Constitutive activity has been reported for a number of established receptors and in many cases characterized further by the use of inverse agonists. Constitutive activity has been reported in a number of orphan receptors, but it does not necessarily mean that an endogenous ligand does exist: Ligands acting at a constitutively active receptor can act as agonists, antagonists, and/or inverse agonists. Secondly, there is no formal definition of what magnitude of basal signaling in the absence of a ligand constitutes intrinsic activity. However, the existence of constitutive activity, particularly when caused by amino acid mutations or other variants, combined with the development of inverse agonists at these receptors has the potential for new strategies for drug development, and with the above caveats, we have highlighted this information where it exists in the literature. Constitutive activity has been reported for EBI2 (Rosenkilde et al., 2006), GPR3 (Eggerickx et al., 1995), GPR6 (Uhlenbrock et al., 2002), GPR12 (Uhlenbrock et al., 2002), GPR17 (BennedJensen and Rosenkilde, 2010), GPR18 (Qin et al., 2011), GPR20 (Hase et al., 2008), GPR22 (Adams et al., 2008), GPR26 (Jones et al., 2007), GPR39 (Holst et al., 2004), GPR61 (Toyooka et al., 2009), GPR78 (Jones et al., 2007), and MAS1 (Canals et al., 2006).

B. C5AR2 (GPR77, C5L2). C5AR2 (Klos et al., 2013) is the first example of a naturally occurring seven-transmembrane segment receptor that is both obligately uncoupled from $G$ proteins and a negative modulator of signal transduction through the $\beta$-arrestin pathway (Bamberg et al., 2010).

C. CCRL1 (CCX-CKR), CCRL2 (CRAM), CCBP2 (D6), and DARC. These proteins do not appear to couple to $\mathrm{G}$ proteins or, in some cases, do not signal through defined pathways. They could all be considered as chemokine binding proteins or "scavengers" that remove chemokines from the local environment, but there is no consensus and no systematic classification can be currently justified. CCRL2 is thought to be a nonsignaling receptor that binds chemerin (IUPHAR-DB ID no. 2945) and increases the local concentration of the peptide (Zabel et al., 2008).

The nomenclature of this family of receptors, which also includes CXCR7 (CMKOR1; see section III.A.5 for further information), is currently being considered by the chemokine receptor subcommittee of NC-IUPHAR.

$D$. GPR50 Is a Negative Regulator of $M T_{1}$ and $M T_{2}$. GPR50 (melatonin-related receptor) is structurally related to the melatonin receptors, $\mathrm{MT}_{1}$ and $\mathrm{MT}_{2}$, but 
does not bind melatonin, and its endogenous ligand has not been identified. GPR50 heterodimerizes constitutively and specifically with $\mathrm{MT}_{1}$ to abolish high-affinity agonist binding and $\mathrm{G}$ protein coupling. Although GPR50 also heterodimerizes with $\mathrm{MT}_{2}$, this had no effect on function and $\mathrm{MT}_{2}$ in intact cells (Levoye et al., 2006).

GPR50 knockout mice showed resistance to dietinduced obesity but lost less weight than wild-type mice when fasted (Ivanova et al., 2008). The mice entered torpor much more readily than wild-type mice in response to fasting or 2-deoxyglucose administration and displayed attenuated responses to leptin and a suppression of thyrotropin-releasing hormone (Bechtold et al., 2012).

\section{Pseudogenes}

Pseudogenes are genomic DNA sequences that display homology to known functional genes but that during the course of evolution acquired mutations that render them nonfunctional. This is often thought to occur when a gene is duplicated and the new copy has an evolutionary window within which it can acquire new functions leading to its preservation, or deleterious mutations may accumulate so that function is irreversibly lost. Thus, a given gene can be functional in some species but not in others. Inactivating mutations can be anywhere in the gene and lead to loss of function at the levels of gene transcription, pre-mRNA processing, translation, or protein folding. The most readily identified disablements are stop codons and frameshifts.

It is fairly obvious that a gene is a pseudogene when it has acquired numerous premature termination codons or shifts in reading frame. NC-IUPHAR has not been concerned about such obvious pseudogenes. However, there are a number of borderline cases that should be considered since our perception of whether they are functional is subject to change. These cases typically have a single mutation leading to a truncated receptor protein. Indeed, there are several cases in which the mutation is now known to be polymorphic, so that the gene appears to be functional in some portion of the human population.

A. GPR33. GPR33 is phylogenetically related to the chemerin receptor (CMKLR1) and GPR1 and has been proposed to function as a chemoattractant receptor (Rompler et al., 2005). It was listed as a functional gene in Foord et al. (2005) but is inactivated by a premature termination codon in a number of species (Rompler et al., 2005). GPR33 appears to be a pseudogene in most individuals, with a premature stop codon at amino acid 140 in the second cytoplasmic loop (Rompler et al., 2005; Bohnekamp et al., 2010; Zhang et al., 2010). According to the National Center for Biotechnology Information dbSNP database (Sherry et al., 2001), this polymorphism, rs17097921, gives the truncated allele in $100 \%$ of Europeans but an active Arg140 allele in 2-8\% of Asians and Africans.
B. TAAR2 and TAAR9. Two of the trace amine receptors are inactivated in a portion of the human population. There is a polymorphism in TAAR2 (rs8192646) producing a premature stop codon at amino acid 168 in $10-15 \%$ of Asians. TAAR9 (formerly TRAR3) appears to be functional in most individuals but has a polymorphic premature stop codon at amino acid 61 (rs2842899) with an allele frequency of $10-30 \%$ in different populations (Vanti et al., 2003). TAAR3 (formerly GPR57) and TAAR4 (current gene symbol, TAAR4P) are thought to be pseudogenes in man though functional in rodents (Lindemann et al., 2005).

C. GPR42. Human GPR42 is closely related to GPR41 (free fatty acid receptor FFA3) and is thought to have arisen from a tandem duplication of GPR41 in the human lineage. Mutagenesis studies have shown that conversion of arginine 174 in the GPR41 protein to tryptophan (found in GPR42) abolishes the response to short-chain fatty acids, raising the possibility that GPR42 might be a translated but inactive pseudogene (Brown et al., 2003). It has been proposed that GPR42 could potentially be a functional gene in a significant fraction of the human population (Liaw and Connolly, 2009), but the very close sequence similarity of GPR41 and GPR42 (six nucleotide differences in the coding sequence) make this very difficult to assess.

$D$. GPR79. GPR79 is a full-length gene in both dog and rodents but is a pseudogene in human (Haitina et al., 2009).The human EMR4 gene (class B: current gene symbol, EMR4P) has a single base deletion in the eighth coding exon compared with other primates and mouse, leading to the expression of a truncated aminoterminal domain of 232 amino acids (Hamann et al., 2003; Caminschi et al., 2006). This protein lacks any of the transmembrane domains of the EMR4 GPCR from other species. There is a second open reading frame capable of encoding a seven-transmembrane GPCR with a 93-amino-acid amino-terminal domain but there is no evidence for its translation. Thus, human EMR4 should be considered as a probable pseudogene, although the 232-amino-acid secreted protein may have biologic function.

$E$. GnRH2. In addition to the classic gonadotrophinreleasing hormone receptor (the $\mathrm{GnRH}$ receptor), some species possess a second $\mathrm{GnRH} 2$ receptor. This gene is absent from the genomes of rats and mice, but a functional gene is present in some primates; the human gene was listed as functional in Foord et al. (2005), but it was subsequently shown that the human gene contains a frameshift mutation and a premature stop codon that would result in translation of a nonfunctional receptor (Morgan et al., 2003). The neuropeptide $Y$ receptor $y 6$ is a pseudogene in human and pig and is absent in rat but generates a functional receptor in rabbit and mouse (Matsumoto et al., 1996; Rose et al., 1997; Starback et al., 2000). 


\section{Conclusion}

Since the original NC-IUPHAR classification of GPCRs in the human genome (Foord et al., 2005), significant progress has been made in assigning endogenous ligands, particularly in class A, and pharmacological tools continue to be developed to delineate these new transmitter systems. There is preliminary evidence for pairings of endogenous ligands of 32 GPCRs in class A, 6 in class B, and 1 in class $\mathrm{C}$, but further research is needed to replicate (or refute) these proposals, particularly as a number of initial claims have been retracted. Most, if not all, human orphan receptors have now been expressed in cell lines, but despite intense effort particularly by the pharmaceutical industry, there is no public information about the cognate ligand for a significant number of them. It is possible that the remaining receptors may function without ligands by being constitutively active or by modulating the activity of other GPCRs, for example, by dimerization (Levoye et al., 2006; Geng et al., 2012). It is clear from knockout studies in mice and genetic deletions in man that these receptors may have a physiological or pathophysiological role and can still be exploited as drug targets in the absence of an identifiable ligand. Further information on all the orphan receptors described in this review can be found on the IUPHAR Database website at http://www.iuphar-db.org.

\section{Acknowledgments}

The authors thank the International Union of Basic and Clinical Pharmacology and British Pharmacological Society for support.

\section{Authorship Contributions}

Performed data analysis: Davenport, Alexander, Sharman, Pawson, Benson, Monaghan, Liew, Mpamhanga, Bonner, Neubig, Pin, Spedding, Harmar.

Wrote or contributed to the manuscript: Davenport, Alexander, Sharman, Pawson, Benson, Mpamhanga, Bonner, Neubig, Pin, Spedding, Harmar.

\section{References}

Retraction (2005) Sphingosylphosphorylcholine and lysophosphatidylcholine are ligands for the G protein-coupled receptor GPR4. J Biol Chem 280:43280.

Adams JW, Wang J, Davis JR, Liaw C, Gaidarov I, Gatlin J, Dalton ND, Gu Y, Ross J Jr, and Behan D, et al. (2008) Myocardial expression, signaling, and function of GPR22: a protective role for an orphan G protein-coupled receptor. Am J Physiol Heart Circ Physiol 295:H509-H521.

Ahmed K, Tunaru S, Langhans CD, Hanson J, Michalski CW, Kölker S, Jones PM, Okun JG, and Offermanns S (2009) Deorphanization of GPR109B as a receptor for the beta-oxidation intermediate 3-OH-octanoic acid and its role in the regulation of lipolysis. J Biol Chem 284:21928-21933.

Ahmed K, Tunaru S, Tang C, Müller M, Gille A, Sassmann A, Hanson J, and Offermanns S (2010) An autocrine lactate loop mediates insulin-dependent inhibition of lipolysis through GPR81. Cell Metab 11:311-319.

Alenina N, Xu P, Rentzsch B, Patkin EL, and Bader M (2008) Genetically altered animal models for Mas and angiotensin-(1-7). Exp Physiol 93:528-537.

Arita M, Ohira T, Sun YP, Elangovan S, Chiang N, and Serhan CN (2007) Resolvin E1 selectively interacts with leukotriene B4 receptor BLT1 and ChemR23 to regulate inflammation. J Immunol 178:3912-3917.

Artmann A, Petersen G, Hellgren LI, Boberg J, Skonberg C, Nellemann C, Hansen $\mathrm{SH}$, and Hansen HS (2008) Influence of dietary fatty acids on endocannabinoid and $\mathrm{N}$-acylethanolamine levels in rat brain, liver and small intestine. Biochim Biophys Acta 1781:200-212.

Balabanian K, Lagane B, Infantino S, Chow KY, Harriague J, Moepps B, ArenzanaSeisdedos F, Thelen M, and Bachelerie F (2005) The chemokine SDF-1/CXCL12 binds to and signals through the orphan receptor RDC1 in T lymphocytes. J Biol Chem 280:35760-35766.

Bamberg CE, Mackay CR, Lee H, Zahra D, Jackson J, Lim YS, Whitfeld PL, Craig S, Corsini E, and Lu B, et al. (2010) The C5a receptor (C5aR) C5L2 is a modulator of C5aR-mediated signal transduction. J Biol Chem 285: 7633-7644.
Barnea G, Strapps W, Herrada G, Berman Y, Ong J, Kloss B, Axel R, and Lee KJ (2008) The genetic design of signaling cascades to record receptor activation. Proc Natl Acad Sci USA 105:64-69.

Bechtold DA, Sidibe A, Saer BR, Li J, Hand LE, Ivanova EA, Darras VM, Dam J, Jockers R, and Luckman SM, et al. (2012) A role for the melatonin-related receptor GPR50 in leptin signaling, adaptive thermogenesis, and torpor. Curr Biol 22: $70-77$.

Bender E, Buist A, Jurzak M, Langlois X, Baggerman G, Verhasselt P, Ercken M, Guo HQ, Wintmolders C, and Van den Wyngaert I, et al. (2002) Characterization of an orphan $\mathrm{G}$ protein-coupled receptor localized in the dorsal root ganglia reveals adenine as a signaling molecule. Proc Natl Acad Sci USA 99:8573-8578.

Benned-Jensen T and Rosenkilde MM (2010) Distinct expression and ligand-binding profiles of two constitutively active GPR17 splice variants. $\mathrm{Br} J$ Pharmacol 159: 1092-1105.

Bodenmüller H and Schaller HC (1981) Conserved amino acid sequence of a neuropeptide, the head activator, from coelenterates to humans. Nature 293:579-580.

Bohnekamp J, Böselt I, Saalbach A, Tönjes A, Kovacs P, Biebermann H, Manvelyan HM, Polte T, Gasperikova D, and Lkhagvasuren S, et al. (2010) Involvement of the chemokine-like receptor GPR33 in innate immunity. Biochem Biophys Res Commun 396:272-277.

Boldajipour B, Mahabaleshwar H, Kardash E, Reichman-Fried M, Blaser H, Minina $\mathrm{S}$, Wilson D, Xu Q, and Raz E (2008) Control of chemokine-guided cell migration by ligand sequestration. Cell 132:463-473.

Bolliger MF, Martinelli DC, and Südhof TC (2011) The cell-adhesion G proteincoupled receptor BAI3 is a high-affinity receptor for C1q-like proteins. Proc Natl Acad Sci USA 108:2534-2539.

Bondarenko A, Waldeck-Weiermair M, Naghdi S, Poteser M, Malli R, and Graier WF (2010) GPR55-dependent and -independent ion signalling in response to lysophosphatidylinositol in endothelial cells. Br J Pharmacol 161:308-320.

Bondue B, Vosters O, de Nadai P, Glineur S, De Henau O, Luangsay S, Van Gool F, Communi D, De Vuyst P, and Desmecht D, et al. (2011a) ChemR23 dampens lung inflammation and enhances anti-viral immunity in a mouse model of acute viral pneumonia. PLoS Pathog 7:e1002358.

Bondue B, Wittamer V, and Parmentier M (2011b) Chemerin and its receptors in leukocyte trafficking, inflammation and metabolism. Cytokine Growth Factor Rev 22:331-338.

Boucard AA, Ko J, and Südhof TC (2012) High affinity neurexin binding to cell adhesion G-protein-coupled receptor CIRL1/latrophilin-1 produces an intercellular adhesion complex. J Biol Chem 287:9399-9413.

Bratton DL and Henson PM (2008) Apoptotic cell recognition: will the real phosphatidylserine receptor(s) please stand up? Curr Biol 18:R76-R79.

Brown AJ, Goldsworthy SM, Barnes AA, Eilert MM, Tcheang L, Daniels D, Muir AI, Wigglesworth MJ, Kinghorn I, and Fraser NJ, et al. (2003) The orphan G proteincoupled receptors GPR41 and GPR43 are activated by propionate and other short chain carboxylic acids. J Biol Chem 278:11312-11319.

Burns JM, Summers BC, Wang Y, Melikian A, Berahovich R, Miao Z, Penfold ME, Sunshine MJ, Littman DR, and Kuo CJ, et al. (2006) A novel chemokine receptor for SDF-1 and I-TAC involved in cell survival, cell adhesion, and tumor development. J Exp Med 203:2201-2213.

Cai TQ, Ren N, Jin L, Cheng K, Kash S, Chen R, Wright SD, Taggart AK, and Waters MG (2008) Role of GPR81 in lactate-mediated reduction of adipose lipolysis. Biochem Biophys Res Commun 377:987-991.

Caminschi I, Vandenabeele S, Sofi M, McKnight AJ, Ward N, Brodnicki TC, Toy T, Lahoud M, Maraskovsky E, Shortman K, et al. (2006) Gene structure and transcript analysis of the human and mouse EGF-TM7 molecule, FIRE. DNA Seq 17: $8-14$.

Canals M, Jenkins L, Kellett E, and Milligan G (2006) Up-regulation of the angiotensin II type 1 receptor by the MAS proto-oncogene is due to constitutive activation of Gq/G11 by MAS. J Biol Chem 281:16757-16767.

Carmon KS, Gong X, Lin Q, Thomas A, and Liu Q (2011) R-spondins function as ligands of the orphan receptors LGR4 and LGR5 to regulate Wnt/beta-catenin signaling. Proc Natl Acad Sci USA 108:11452-11457.

Cartoni C, Yasumatsu K, Ohkuri T, Shigemura N, Yoshida R, Godinot N, le Coutre J, Ninomiya Y, and Damak S (2010) Taste preference for fatty acids is mediated by GPR40 and GPR120. J Neurosci 30:8376-8382.

Cash JL, Christian AR, and Greaves DR (2010) Chemerin peptides promote phagocytosis in a ChemR23- and Syk-dependent manner. J Immunol 184:5315-5324.

Chartrel N, Alvear-Perez R, Leprince J, Iturrioz X, Reaux-Le Goazigo A, Audinot V, Chomarat P, Coge F, Nosjean O, and Rodriguez M, et al. (2007) Comment on "Obestatin, a peptide encoded by the ghrelin gene, opposes ghrelin's effects on food intake". Science 315:766-, author reply 766 .

Chen $\mathrm{H}$ and Ikeda SR (2004) Modulation of ion channels and synaptic transmission by a human sensory neuron-specific G-protein-coupled receptor, SNSR4/mrgX1, heterologously expressed in cultured rat neurons. J Neurosci 24:5044-5053.

Chiang N, Fredman G, Bäckhed F, Oh SF, Vickery T, Schmidt BA, and Serhan CN (2012) Infection regulates pro-resolving mediators that lower antibiotic requirements. Nature 484:524-528.

Christiansen B, Hansen KB, Wellendorph P, and Bräuner-Osborne H (2007) Pharmacological characterization of mouse GPRC6A, an L-alpha-amino-acid receptor modulated by divalent cations. Br J Pharmacol 150:798-807.

Chu ZL, Carroll C, Chen R, Alfonso J, Gutierrez V, He H, Lucman A, Xing C, Sebring $\mathrm{K}$, and Zhou J, et al. (2010) N-Oleoyldopamine enhances glucose homeostasis through the activation of GPR119. Mol Endocrinol 24:161-170.

Chun J, Hla T, Lynch KR, Spiegel S, and Moolenaar WH (2010) International Union of Basic and Clinical Pharmacology. LXXVIII. Lysophospholipid receptor nomenclature. Pharmacol Rev 62:579-587.

Ciana P, Fumagalli M, Trincavelli ML, Verderio C, Rosa P, Lecca D, Ferrario S, Parravicini C, Capra V, and Gelosa P, et al. (2006) The orphan receptor GPR17 identified as a new dual uracil nucleotides/cysteinyl-leukotrienes receptor. EMBO J 25:4615-4627. 
Civelli O (2012) Orphan GPCRs and neuromodulation. Neuron 76:12-21.

Crozier RA, Ajit SK, Kaftan EJ, and Pausch MH (2007) MrgD activation inhibits KCNQ/M-currents and contributes to enhanced neuronal excitability. $J$ Neurosci 27:4492-4496.

Davenport AP, Bonner TI, Foord SM, Harmar AJ, Neubig RR, Pin JP, Spedding M, Kojima M, and Kangawa K (2005) International Union of Pharmacology. LVI. Ghrelin receptor nomenclature, distribution, and function. Pharmacol Rev 57: 541-546.

de Lau W, Barker N, Low TY, Koo BK, Li VS, Teunissen H, Kujala P, Haegebarth A, Peters PJ, and van de Wetering M, et al. (2011) Lgr5 homologues associate with Wnt receptors and mediate R-spondin signalling. Nature 476:293-297.

de Lecea L, Criado JR, Prospero-Garcia O, Gautvik KM, Schweitzer P, Danielson PE, Dunlop CL, Siggins GR, Henriksen SJ, and Sutcliffe JG (1996) A cortical neuropeptide with neuronal depressant and sleep-modulating properties. Nature $\mathbf{3 8 1}$ $242-245$

Deng H, Hu H, and Fang Y (2012) Multiple tyrosine metabolites are GPR35 agonists. Sci Rep 2:373.

Dong X, Han S, Zylka MJ, Simon MI, and Anderson DJ (2001) A diverse family of GPCRs expressed in specific subsets of nociceptive sensory neurons. Cell 106 619-632.

Eggerickx D, Denef JF, Labbe O, Hayashi Y, Refetoff S, Vassart G, Parmentier M, and Libert F (1995) Molecular cloning of an orphan G-protein-coupled receptor that constitutively activates adenylate cyclase. Biochem $J$ 309:837-843.

Eppig JT, Blake JA, Bult CJ, Kadin JA, and Richardson JE; Mouse Genome Database Group (2012) The Mouse Genome Database (MGD): comprehensive resource for genetics and genomics of the laboratory mouse. Nucleic Acids Res $\mathbf{4 0}$ (Database issue):D881-D886

Fallarini S, Magliulo L, Paoletti T, de Lalla C, and Lombardi G (2010) Expression of functional GPR35 in human iNKT cells. Biochem Biophys Res Commun 398: $420-425$.

Foord SM, Bonner TI, Neubig RR, Rosser EM, Pin JP, Davenport AP, Spedding M, and Harmar AJ (2005) International Union of Pharmacology. XLVI. G proteincoupled receptor list. Pharmacol Rev 57:279-288.

Ford LA, Roelofs AJ, Anavi-Goffer S, Mowat L, Simpson DG, Irving AJ, Rogers MJ, Rajnicek AM, and Ross RA (2010) A role for L-alpha-lysophosphatidylinositol and GPR55 in the modulation of migration, orientation and polarization of human breast cancer cells. Br J Pharmacol 160:762-771.

Geng Y, Xiong D, Mosyak L, Malito DL, Kniazeff J, Chen Y, Burmakina S, Quick M, Bush M, and Javitch JA, et al. (2012) Structure and functional interaction of the extracellular domain of human GABA(B) receptor GBR2. Nat Neurosci 15:970-978. Gerrits H, van Ingen Schenau DS, Bakker NE, van Disseldorp AJ, Strik A, Hermens LS, Koenen TB, Krajnc-Franken MA, and Gossen JA (2008) Early postnatal lethality and cardiovascular defects in CXCR7-deficient mice. Genesis 46:235-245.

Gloriam DE, Fredriksson R, and Schiöth HB (2007) The G protein-coupled receptor subset of the rat genome. BMC Genomics 8:338.

Godlewski G, Offertáler L, Wagner JA, and Kunos G (2009) Receptors for acylethanolamides-GPR55 and GPR119. Prostaglandins Other Lipid Mediat 89 105-111.

Gong X, Carmon KS, Lin Q, Thomas A, Yi J, and Liu Q (2012) LGR6 is a high affinity receptor of R-spondins and potentially functions as a tumor suppressor. PLoS ONE 7:e37137.

Guo Y, Zhang W, Giroux C, Cai Y, Ekambaram P, Dilly AK, Hsu A, Zhou S, Maddipati $\mathrm{KR}$, and Liu J, et al. (2011) Identification of the orphan G protein-coupled receptor GPR31 as a receptor for 12-(S)-hydroxyeicosatetraenoic acid. J Biol Chem 286 $33832-33840$

Haitina T, Fredriksson R, Foord SM, Schiöth HB, and Gloriam DE (2009) The G protein-coupled receptor subset of the dog genome is more similar to that in humans than rodents. BMC Genomics 10:24

Hamann J, Kwakkenbos MJ, de Jong EC, Heus H, Olsen AS, and van Lier RA (2003) Inactivation of the EGF-TM7 receptor EMR4 after the Pan-Homo divergence. Eur $J$ Immunol 33:1365-1371.

Hamann J, Vogel B, van Schijndel GM, and van Lier RA (1996) The seven-span transmembrane receptor CD97 has a cellular ligand (CD55, DAF). J Exp Med 184 $1185-1189$

Han SK, Dong X, Hwang JI, Zylka MJ, Anderson DJ, and Simon MI (2002) Orphan G protein-coupled receptors $\mathrm{MrgA} 1$ and $\mathrm{MrgC} 11$ are distinctively activated by RFamide-related peptides through the Galpha q/11 pathway. Proc Natl Acad Sci USA 99:14740-14745.

Hannedouche S, Zhang J, Yi T, Shen W, Nguyen D, Pereira JP, Guerini D, Baumgarten BU, Roggo S, and Wen B, et al. (2011) Oxysterols direct immune cell migration via EBI2. Nature 475:524-527.

Hansen KB, Rosenkilde MM, Knop FK, Wellner N, Diep TA, Rehfeld JF, Andersen UB, Holst JJ, and Hansen HS (2011) 2-Oleoyl glycerol is a GPR119 agonist and signals GLP-1 release in humans. J Clin Endocrinol Metab 96: E1409-E1417.

Hanson MA, Roth CB, Jo E, Griffith MT, Scott FL, Reinhart G, Desale H, Clemons B, Cahalan SM, and Schuerer SC, et al. (2012) Crystal structure of a lipid G proteincoupled receptor. Science 335:851-855.

Hart R and Greaves DR (2010) Chemerin contributes to inflammation by promoting macrophage adhesion to VCAM-1 and fibronectin through clustering of VLA-4 and VLA-5. J Immunol 185:3728-3739.

Hase M, Yokomizo T, Shimizu T, and Nakamura M (2008) Characterization of an orphan G protein-coupled receptor, GPR20, that constitutively activates Gi proteins. J Biol Chem 283:12747-12755.

He W, Miao FJ, Lin DC, Schwandner RT, Wang Z, Gao J, Chen JL, Tian H, and Ling L (2004) Citric acid cycle intermediates as ligands for orphan G-protein-coupled receptors. Nature 429:188-193.

Henstridge CM, Balenga NA, Ford LA, Ross RA, Waldhoer M, and Irving AJ (2009) The GPR55 ligand L-alpha-lysophosphatidylinositol promotes RhoA-dependent Ca2+ signaling and NFAT activation. FASEB $J$ 23:183-193.
Henstridge CM, Balenga NA, Schröder R, Kargl JK, Platzer W, Martini L, Arthur S, Penman J, Whistler JL, and Kostenis E, et al. (2010) GPR55 ligands promote receptor coupling to multiple signalling pathways. $\mathrm{Br} J$ Pharmacol 160:604-614.

Hirasawa A, Tsumaya K, Awaji T, Katsuma S, Adachi T, Yamada M, Sugimoto Y, Miyazaki S, and Tsujimoto G (2005) Free fatty acids regulate gut incretin glucagon-like peptide-1 secretion through GPR120. Nat Med 11:90-94.

Holst B, Egerod KL, Schild E, Vickers SP, Cheetham S, Gerlach LO, Storjohann L, Stidsen CE, Jones R, and Beck-Sickinger AG, et al. (2007) GPR39 signaling is stimulated by zinc ions but not by obestatin. Endocrinology 148:13-20.

Holst B, Holliday ND, Bach A, Elling CE, Cox HM, and Schwartz TW (2004) Common structural basis for constitutive activity of the ghrelin receptor family. J Biol Chem 279:53806-53817.

Hsu SY, Kudo M, Chen T, Nakabayashi K, Bhalla A, van der Spek PJ, van Duin M, and Hsueh AJ (2000) The three subfamilies of leucine-rich repeat-containing G protein-coupled receptors (LGR): identification of LGR6 and LGR7 and the signaling mechanism for LGR7. Mol Endocrinol 14:1257-1271.

Hsu SY, Liang SG, and Hsueh AJ (1998) Characterization of two LGR genes homologous to gonadotropin and thyrotropin receptors with extracellular leucine-rich repeats and a G protein-coupled, seven-transmembrane region. Mol Endocrinol 12 $1830-1845$.

Hu H, Deng H, and Fang Y (2012) Label-free phenotypic profiling identified Dluciferin as a GPR35 agonist. PLoS ONE 7:e34934.

Ichimura A, Hirasawa A, Poulain-Godefroy O, Bonnefond A, Hara T, Yengo L, Kimura I, Leloire A, Liu N, and Iida K, et al. (2012) Dysfunction of lipid sensor GPR120 leads to obesity in both mouse and human. Nature 483:350-354.

Ignatov A, Robert J, Gregory-Evans C, and Schaller HC (2006) RANTES stimulates $\mathrm{Ca} 2+$ mobilization and inositol trisphosphate (IP3) formation in cells transfected with G protein-coupled receptor 75. Br J Pharmacol 149:490-497.

Ishida J, Hashimoto T, Hashimoto Y, Nishiwaki S, Iguchi T, Harada S, Sugaya T, Matsuzaki H, Yamamoto R, and Shiota N, et al. (2004) Regulatory roles for APJ, a seven-transmembrane receptor related to angiotensin-type 1 receptor in blood pressure in vivo. J Biol Chem 279:26274-26279.

Ishiguro H, Onaivi ES, Horiuchi Y, Imai K, Komaki G, Ishikawa T, Suzuki M, Watanabe Y, Ando T, and Higuchi S, et al. (2011) Functional polymorphism in the GPR55 gene is associated with anorexia nervosa. Synapse 65:103-108.

Ivanova EA, Bechtold DA, Dupré SM, Brennand J, Barrett P, Luckman SM, and Loudon AS (2008) Altered metabolism in the melatonin-related receptor (GPR50) knockout mouse. Am J Physiol Endocrinol Metab 294:E176-E182.

Iwashita M, Makide K, Nonomura T, Misumi Y, Otani Y, Ishida M, Taguchi R, Tsujimoto M, Aoki J, and Arai H, et al. (2009) Synthesis and evaluation of lysophosphatidylserine analogues as inducers of mast cell degranulation. Potent ac tivities of lysophosphatidylthreonine and its 2-deoxy derivative. J Med Chem 52: $5837-5863$

Jones PG, Nawoschik SP, Sreekumar K, Uveges AJ, Tseng E, Zhang L, Johnson J, He L, Paulsen JE, and Bates B, et al. (2007) Tissue distribution and functional analyses of the constitutively active orphan $\mathrm{G}$ protein coupled receptors, GPR26 and GPR78. Biochim Biophys Acta 1770:890-901.

Kamohara M, Matsuo A, Takasaki J, Kohda M, Matsumoto M, Matsumoto S, Soga T, Hiyama H, Kobori M, and Katou M (2005) Identification of MrgX2 as a human G-protein-coupled receptor for proadrenomedullin N-terminal peptides. Biochem Biophys Res Commun 330:1146-1152.

Kapas S, Catt KJ, and Clark AJ (1995) Cloning and expression of cDNA encoding a rat adrenomedullin receptor. J Biol Chem 270:25344-25347.

Kaplan MH, Smith DI, and Sundick RS (1993) Identification of a G protein coupled receptor induced in activated $\mathrm{T}$ cells. J Immunol 151:628-636.

Kapur A, Zhao P, Sharir H, Bai Y, Caron MG, Barak LS, and Abood ME (2009) Atypical responsiveness of the orphan receptor GPR55 to cannabinoid ligands. $J$ Biol Chem 284:29817-29827.

Kennedy SP, Sun D, Oleynek JJ, Hoth CF, Kong J, and Hill RJ (1998) Expression of the rat adrenomedullin receptor or a putative human adrenomedullin receptor does not correlate with adrenomedullin binding or functional response. Biochem Biophys Res Commun 244:832-837.

Kirby HR, Maguire JJ, Colledge WH, and Davenport AP (2010) International Union of Basic and Clinical Pharmacology. LXXVII. Kisspeptin receptor nomenclature, distribution, and function. Pharmacol Rev 62:565-578.

Kitamura H, Makide K, Shuto A, Ikubo M, Inoue A, Suzuki K, Sato Y, Nakamura S, Otani Y, and Ohwada T, et al. (2012) GPR34 is a receptor for lysophosphatidylserine with a fatty acid at the sn-2 position. J Biochem 151:511-518.

Kleist B, Xu L, Li G, and Kersten C (2011) Expression of the adult intestinal stem cell marker Lgr5 in the metastatic cascade of colorectal cancer. Int J Clin Exp Pathol 4 : $327-335$

Klos A, Wende E, Wareham KJ, and Monk PN (2013) International Union of Pharmacology. LXXXVII. Complement peptide C5a, C4a, and C3a receptors. Pharmacol Rev 65:500-543.

Kohno M, Hasegawa H, Inoue A, Muraoka M, Miyazaki T, Oka K, and Yasukawa (2006) Identification of $\mathrm{N}$-arachidonylglycine as the endogenous ligand for orphan G-protein-coupled receptor GPR18. Biochem Biophys Res Commun 347:827-832.

Kostenis E (2004) Novel clusters of receptors for sphingosine-1-phosphate, sphingosylphosphorylcholine, and (lyso)-phosphatidic acid: new receptors for "old" ligands. J Cell Biochem 92:923-936.

Kotarsky K, Boketoft A, Bristulf J, Nilsson NE, Norberg A, Hansson S, Owman C, Sillard R, Leeb-Lundberg LM, and Olde B (2006) Lysophosphatidic acid binds to and activates GPR92, a G protein-coupled receptor highly expressed in gastrointestinal lymphocytes. $J$ Pharmacol Exp Ther 318:619-628.

Krishnamoorthy S, Recchiuti A, Chiang N, Fredman G, and Serhan CN (2012) Resolvin D1 receptor stereoselectivity and regulation of inflammation and proresolving microRNAs. Am J Pathol 180:2018-2027.

Krishnamoorthy S, Recchiuti A, Chiang N, Yacoubian S, Lee CH, Yang R, Petasis NA, and Serhan CN (2010) Resolvin D1 binds human phagocytes with evidence for proresolving receptors. Proc Natl Acad Sci USA 107:1660-1665. 
Kuc D, Zgrajka W, Parada-Turska J, Urbanik-Sypniewska T, and Turski WA (2008) Micromolar concentration of kynurenic acid in rat small intestine. Amino Acids $\mathbf{3 5}$ 503-505.

Lagerström MC and Schiöth HB (2008) Structural diversity of G protein-coupled receptors and significance for drug discovery. Nat Rev Drug Discov 7:339-357.

Lan H, Vassileva G, Corona A, Liu L, Baker H, Golovko A, Abbondanzo SJ, Hu W, Yang S, and Ning Y, et al. (2009) GPR119 is required for physiological regulation of glucagon-like peptide-1 secretion but not for metabolic homeostasis. J Endocrinol 201:219-230.

Lauckner JE, Jensen JB, Chen HY, Lu HC, Hille B, and Mackie K (2008) GPR55 is a cannabinoid receptor that increases intracellular calcium and inhibits $\mathrm{M}$ current. Proc Natl Acad Sci USA 105:2699-2704.

Lauring B, Taggart AK, Tata JR, Dunbar R, Caro L, Cheng K, Chin J, Colletti SL, Cote J, Khalilieh S, et al. (2012) Niacin lipid efficacy is independent of both the niacin receptor GPR109A and free fatty acid suppression. Sci Transl Med 4 $148 \mathrm{ra} 115$.

Lauwers E, Landuyt B, Arckens L, Schoofs L, and Luyten W (2006) Obestatin does not activate orphan G protein-coupled receptor GPR39. Biochem Biophys Res Commun 351:21-25.

Lee CW, Rivera R, Gardell S, Dubin AE, and Chun J (2006) GPR92 as a new G12/13and Gq-coupled lysophosphatidic acid receptor that increases cAMP, LPA5. J Biol Chem 281:23589-23597.

Lee MG, Dong X, Liu Q, Patel KN, Choi OH, Vonakis B, and Undem BJ (2008a) Agonists of the MAS-related gene (Mrgs) orphan receptors as novel mediators of mast cell-sensory nerve interactions. $J$ Immunol 180·2251-2255.

Lee Z, Cheng CT, Zhang H, Subler MA, Wu J, Mukherjee A, Windle JJ, Chen CK, and Fang X (2008b) Role of LPA4/p2y9/GPR23 in negative regulation of cell motility. Mol Biol Cell 19:5435-5445.

Leick M, Catusse J, Follo M, Nibbs RJ, Hartmann TN, Veelken H, and Burger M (2010) CCL19 is a specific ligand of the constitutively recycling atypical human chemokine receptor CRAM-B. Immunology 129:536-546.

Lembo PM, Grazzini E, Groblewski T, O’Donnell D, Roy MO, Zhang J, Hoffert C, Cao J, Schmidt R, and Pelletier M, et al. (2002) Proenkephalin A gene products activate a new family of sensory neuron-specific GPCRs. Nat Neurosci 5:201-209.

Levoye A, Dam J, Ayoub MA, Guillaume JL, Couturier C, Delagrange P, and Jockers R (2006) The orphan GPR50 receptor specifically inhibits MT1 melatonin receptor function through heterodimerization. EMBO $J$ 25:3012-3023.

Liaw CW and Connolly DT (2009) Sequence polymorphisms provide a common consensus sequence for GPR41 and GPR42. DNA Cell Biol 28:555-560.

Lin HH, Stacey M, Saxby C, Knott V, Chaudhry Y, Evans D, Gordon S, McKnight AJ, Handford P, and Lea S (2001) Molecular analysis of the epidermal growth factorlike short consensus repeat domain-mediated protein-protein interactions: dissection of the CD97-CD55 complex. J Biol Chem 276:24160-24169.

Lin ME, Rivera RR, and Chun J (2012) Targeted deletion of LPA5 identifies novel roles for lysophosphatidic acid signaling in development of neuropathic pain. J Biol Chem 287:17608-17617.

Lindemann L, Ebeling M, Kratochwil NA, Bunzow JR, Grandy DK, and Hoener MC (2005) Trace amine-associated receptors form structurally and functionally distinct subfamilies of novel G protein-coupled receptors. Genomics 85:372-385.

Liu C, Yang XV, Wu J, Kuei C, Mani NS, Zhang L, Yu J, Sutton SW, Qin N, and Banie H, et al. (2011) Oxysterols direct B-cell migration through EBI2. Nature 475:519-523.

Liu Q, Tang Z, Surdenikova L, Kim S, Patel KN, Kim A, Ru F, Guan Y, Weng HJ, and Geng Y, et al. (2009) Sensory neuron-specific GPCR Mrgprs are itch receptors mediating chloroquine-induced pruritus. Cell 139:1353-1365.

Luangsay S, Wittamer V, Bondue B, De Henau O, Rouger L, Brait M, Franssen JD, de Nadai P, Huaux F, and Parmentier M (2009) Mouse ChemR23 is expressed in dendritic cell subsets and macrophages, and mediates an anti-inflammatory activity of chemerin in a lung disease model. J Immunol 183:6489-6499.

Ludwig MG, Vanek M, Guerini D, Gasser JA, Jones CE, Junker U, Hofstetter H, Wolf RM, and Seuwen K (2003) Proton-sensing G-protein-coupled receptors. Nature 425: 93-98.

Luo R, Jeong SJ, Jin Z, Strokes N, Li S, and Piao X (2011) G protein-coupled receptor 56 and collagen III, a receptor-ligand pair, regulates cortical development and lamination. Proc Natl Acad Sci USA 108:12925-12930.

Maekawa A, Balestrieri B, Austen KF, and Kanaoka Y (2009) GPR17 is a negative regulator of the cysteinyl leukotriene 1 receptor response to leukotriene D4. Proc Natl Acad Sci USA 106:11685-11690.

Maguire JJ, Parker WA, Foord SM, Bonner TI, Neubig RR, and Davenport AP (2009) International Union of Pharmacology. LXXII. Recommendations for trace amine receptor nomenclature. Pharmacol Rev 61:1-8.

Malik L, Kelly NM, Ma JN, Currier EA, Burstein ES, and Olsson R (2009) Discovery of non-peptidergic MrgX1 and MrgX2 receptor agonists and exploration of an initial SAR using solid-phase synthesis. Bioorg Med Chem Lett 19:1729-1732.

Marazziti D, Di Pietro C, Golini E, Mandillo S, Matteoni R, and Tocchini-Valentini GP (2009) Induction of macroautophagy by overexpression of the Parkinson's disease-associated GPR37 receptor. FASEB J 23:1978-1987.

Marazziti D, Di Pietro C, Mandillo S, Golini E, Matteoni R, and Tocchini-Valentini GP (2011) Absence of the GPR37/PAEL receptor impairs striatal Akt and ERK2 phosphorylation, DeltaFosB expression, and conditioned place preference to amphetamine and cocaine. FASEB $J$ 25:2071-2081.

Marazziti D, Mandillo S, Di Pietro C, Golini E, Matteoni R, and Tocchini-Valentini GP (2007) GPR37 associates with the dopamine transporter to modulate dopamine uptake and behavioral responses to dopaminergic drugs. Proc Natl Acad Sci USA 104:9846-9851.

Mårtensson UE, Salehi SA, Windahl S, Gomez MF, Swärd K, Daszkiewicz-Nilsson J, Wendt A, Andersson N, Hellstrand P, and Grände PO, et al. (2009) Deletion of the $\mathrm{G}$ protein-coupled receptor 30 impairs glucose tolerance, reduces bone growth, increases blood pressure, and eliminates estradiol-stimulated insulin release in female mice. Endocrinology 150:687-698.
Maruyama T, Miyamoto Y, Nakamura T, Tamai Y, Okada H, Sugiyama E, Nakamura $\mathrm{T}$, Itadani H, and Tanaka K (2002) Identification of membrane-type receptor for bile acids (M-BAR). Biochem Biophys Res Commun 298:714-719.

Matsumoto M, Nomura T, Momose K, Ikeda Y, Kondou Y, Akiho H, Togami J, Kimura Y, Okada M, and Yamaguchi T (1996) Inactivation of a novel neuropeptide Y/peptide YY receptor gene in primate species. J Biol Chem 271:27217-27220.

McHugh D, Hu SS, Rimmerman N, Juknat A, Vogel Z, Walker JM, and Bradshaw HB (2010) N-Arachidonoyl glycine, an abundant endogenous lipid, potently drives directed cellular migration through GPR18, the putative abnormal cannabidiol receptor. BMC Neurosci 11:44.

McHugh D, Page J, Dunn E, and Bradshaw HB (2012) $\Delta\left(^{9}\right)$-Tetrahydrocannabinol and $\mathrm{N}$-arachidonyl glycine are full agonists at GPR18 receptors and induce migration in human endometrial HEC-1B cells. Br J Pharmacol 165:2414-2424

Meder W, Wendland M, Busmann A, Kutzleb C, Spodsberg N, John H, Richter R Schleuder D, Meyer M, and Forssmann WG (2003) Characterization of human circulating TIG2 as a ligand for the orphan receptor ChemR23. FEBS Lett 555: 495-499.

Meyer zu Heringdorf D and Jakobs KH (2007) Lysophospholipid receptors: signalling, pharmacology and regulation by lysophospholipid metabolism. Biochim Biophys Acta 1768:923-940.

Milasta S, Pediani J, Appelbe S, Trim S, Wyatt M, Cox P, Fidock M, and Milligan G (2006) Interactions between the Mas-related receptors MrgD and MrgE alter signalling and trafficking of MrgD. Mol Pharmacol 69:479-491.

Moechars D, Depoortere I, Moreaux B, de Smet B, Goris I, Hoskens L, Daneels G, Kass S, Ver Donck L, and Peeters T, et al. (2006) Altered gastrointestinal and metabolic function in the GPR39-obestatin receptor-knockout mouse. Gastroenterology 131:1131-1141.

Morgan K, Conklin D, Pawson AJ, Sellar R, Ott TR, and Millar RP (2003) A transcriptionally active human type II gonadotropin-releasing hormone receptor gene homolog overlaps two genes in the antisense orientation on chromosome 1q.12. Endocrinology 144:423-436.

Murakami M, Shiraishi A, Tabata K, and Fujita N (2008) Identification of the orphan GPCR, P2Y(10) receptor as the sphingosine-1-phosphate and lysophosphatidic acid receptor. Biochem Biophys Res Commun 371:707-712.

Murakami N, Yokomizo T, Okuno T, and Shimizu T (2004) G2A is a proton-sensing G-protein-coupled receptor antagonized by lysophosphatidylcholine. J Biol Chem 279:42484-42491.

Neubig RR (2010) Mind your salts: when the inactive constituent isn't. Mol Pharmacol 78:558-559.

Ning Y, O’Neill K, Lan H, Pang L, Shan LX, Hawes BE, and Hedrick JA (2008) Endogenous and synthetic agonists of GPR119 differ in signalling pathways and their effects on insulin secretion in MIN6c4 insulinoma cells. $\mathrm{Br} J$ Pharmacol 155: 1056-1065.

Noguchi K, Ishii S, and Shimizu T (2003) Identification of p2y9/GPR23 as a novel G protein-coupled receptor for lysophosphatidic acid, structurally distant from the Edg family. J Biol Chem 278:25600-25606.

Nonaka Y, Hiramoto T, and Fujita N (2005) Identification of endogenous surrogate ligands for human P2Y12 receptors by in silico and in vitro methods. Biochem Biophys Res Commun 337:281-288.

Nothacker HP, Wang Z, Zeng H, Mahata SK, O'Connor DT, and Civelli O (2005) Proadrenomedullin N-terminal peptide and cortistatin activation of MrgX2 receptor is based on a common structural motif. Eur $J$ Pharmacol 519:191-193.

O'Sullivan ML, de Wit J, Savas JN, Comoletti D, Otto-Hitt S, Yates JR 3rd, and Ghosh A (2012) FLRT proteins are endogenous latrophilin ligands and regulate excitatory synapse development. Neuron 73:903-910.

Offermanns S, Colletti SL, Lovenberg TW, Semple G, Wise A, and IJzerman AP (2011) International Union of Basic and Clinical Pharmacology. LXXXII: Nomenclature and Classification of Hydroxy-carboxylic Acid Receptors (GPR81, GPR109A, and GPR109B). Pharmacol Rev 63:269-290.

Oka S, Kimura S, Toshida T, Ota R, Yamashita A, and Sugiura T (2010a) Lysophosphatidylinositol induces rapid phosphorylation of p38 mitogen-activated protein kinase and activating transcription factor 2 in HEK293 cells expressing GPR55 and IM-9 lymphoblastoid cells. J Biochem 147:671-678.

Oka S, Nakajima K, Yamashita A, Kishimoto S, and Sugiura T (2007) Identification of GPR55 as a lysophosphatidylinositol receptor. Biochem Biophys Res Commun 362.928-934.

Oka S, Ota R, Shima M, Yamashita A, and Sugiura T (2010b) GPR35 is a novel lysophosphatidic acid receptor. Biochem Biophys Res Commun 395:232-237.

Oka S, Toshida T, Maruyama K, Nakajima K, Yamashita A, and Sugiura T (2009) 2-Arachidonoyl-sn-glycero-3-phosphoinositol: a possible natural ligand for GPR55. $J$ Biochem 145:13-20.

Oury F, Sumara G, Sumara O, Ferron M, Chang H, Smith CE, Hermo L, Suarez S, Roth BL, and Ducy P, et al. (2011) Endocrine regulation of male fertility by the skeleton. Cell 144:796-809.

Overton HA, Babbs AJ, Doel SM, Fyfe MC, Gardner LS, Griffin G, Jackson HC, Procter MJ, Rasamison CM, and Tang-Christensen M, et al. (2006) Deorphanization of a $G$ protein-coupled receptor for oleoylethanolamide and its use in the discovery of small-molecule hypophagic agents. Cell Metab 3:167-175.

Park D, Tosello-Trampont AC, Elliott MR, Lu M, Haney LB, Ma Z, Klibanov AL, Mandell JW, and Ravichandran KS (2007) BAI1 is an engulfment receptor for apoptotic cells upstream of the ELMO/Dock180/Rac module. Nature 450: $430-434$

Pasternack SM, von Kügelgen I, Al Aboud K, Lee YA, Rüschendorf F, Voss K, Hillmer AM, Molderings GJ, Franz T, and Ramirez A, et al. (2008) G protein-coupled receptor P2Y5 and its ligand LPA are involved in maintenance of human hair growth. Nat Genet 40:329-334.

Pertwee RG, Howlett AC, Abood ME, Alexander SP, Di Marzo V, Elphick MR, Greasley PJ, Hansen HS, Kunos G, and Mackie K, et al. (2010) International Union of Basic and Clinical Pharmacology. LXXIX. Cannabinoid receptors and their ligands: beyond $\mathrm{CB}_{1}$ and $\mathrm{CB}_{2}$. Pharmacol Rev 62:588-631. 
Petersen PS, Jin C, Madsen AN, Rasmussen M, Kuhre R, Egerod KL, Nielsen LB, Schwartz TW, and Holst B (2011) Deficiency of the GPR39 receptor is associated with obesity and altered adipocyte metabolism. FASEB $J$ 25:3803-3814.

Pi M, Parrill AL, and Quarles LD (2010) GPRC6A mediates the non-genomic effects of steroids. J Biol Chem 285:39953-39964.

Pi M, Wu Y, Lenchik NI, Gerling I, and Quarles LD (2012) GPRC6A mediates the effects of L-arginine on insulin secretion in mouse pancreatic islets. Endocrinology 153:4608-4615.

Pi M, Wu Y, and Quarles LD (2011) GPRC6A mediates responses to osteocalcin in $\beta$-cells in vitro and pancreas in vivo. J Bone Miner Res 26:1680-1683.

Piñeiro R, Maffucci T, and Falasca M (2011) The putative cannabinoid receptor GPR55 defines a novel autocrine loop in cancer cell proliferation. Oncogene 30: 142-152.

Pitkin SL, Maguire JJ, Bonner TI, and Davenport AP (2010) International Union of Basic and Clinical Pharmacology. LXXIV. Apelin receptor nomenclature, distribution, pharmacology, and function. Pharmacol Rev 62:331-342.

Popovics P and Stewart AJ (2011) GPR39: a Zn(2+)-activated G protein-coupled receptor that regulates pancreatic, gastrointestinal and neuronal functions. Cell $\mathrm{Mol}$ Life Sci 68:85-95.

Prossnitz ER and Barton M (2011) The G-protein-coupled estrogen receptor GPER in health and disease. Nat Rev Endocrinol 7:715-726.

Qian YM, Haino M, Kelly K, and Song WC (1999) Structural characterization of mouse CD97 and study of its specific interaction with the murine decayaccelerating factor (DAF, CD55). Immunology 98:303-311.

Qin Y, Verdegaal EM, Siderius M, Bebelman JP, Smit MJ, Leurs R, Willemze R, Tensen CP, and Osanto S (2011) Quantitative expression profiling of G-proteincoupled receptors (GPCRs) in metastatic melanoma: the constitutively active or phan GPCR GPR18 as novel drug target. Pigment Cell Melanoma Res 24:207-218.

Rajagopal S, Kim J, Ahn S, Craig S, Lam CM, Gerard NP, Gerard C, and Lefkowitz RJ (2010) Beta-arrestin- but not G protein-mediated signaling by the "decoy" receptor CXCR7. Proc Natl Acad Sci USA 107:628-632.

Revankar CM, Cimino DF, Sklar LA, Arterburn JB, and Prossnitz ER (2005) A transmembrane intracellular estrogen receptor mediates rapid cell signaling. Science 307:1625-1630.

Rezgaoui M, Süsens U, Ignatov A, Gelderblom M, Glassmeier G, Franke I, Urny J, Imai Y, Takahashi R, and Schaller HC (2006) The neuropeptide head activator is a high-affinity ligand for the orphan G-protein-coupled receptor GPR37. J Cell Sci 119:542-549.

Ritscher L, Engemaier E, Stäubert C, Liebscher I, Schmidt P, Hermsdorf T, Römpler $\mathrm{H}$, Schulz A, and Schöneberg T (2012) The ligand specificity of the G-proteincoupled receptor GPR34. Biochem J 443:841-850.

Robas N, Mead E, and Fidock M (2003) MrgX2 is a high potency cortistatin receptor expressed in dorsal root ganglion. J Biol Chem 278:44400-44404

Römpler H, Schulz A, Pitra C, Coop G, Przeworski M, Pääbo S, and Schöneberg T (2005) The rise and fall of the chemoattractant receptor GPR33. J Biol Chem 280 31068-31075.

Rose PM, Lynch JS, Frazier ST, Fisher SM, Chung W, Battaglino P, Fathi Z, Leibel $R$, and Fernandes $P$ (1997) Molecular genetic analysis of a human neuropeptide $Y$ receptor. The human homolog of the murine "Y5" receptor may be a pseudogene. $J$ Biol Chem 272:3622-3627.

Rosenkilde MM, Benned-Jensen T, Andersen H, Holst PJ, Kledal TN, Lüttichau HR Larsen JK, Christensen JP, and Schwartz TW (2006) Molecular pharmacological phenotyping of EBI2. An orphan seven-transmembrane receptor with constitutive activity. J Biol Chem 281:13199-13208.

Ross RA (2009) The enigmatic pharmacology of GPR55. Trends Pharmacol Sci 30: $156-163$

Ross RA (2011) L- $\alpha$-lysophosphatidylinositol meets GPR55: a deadly relationship. Trends Pharmacol Sci 32:265-269.

Santos RA, Simoes e Silva AC, Maric C, Silva DM, Machado RP, de Buhr I, HeringerWalther S, Pinheiro SV, Lopes MT, and Bader M, et al. (2003) Angiotensin-(1-7) is an endogenous ligand for the G protein-coupled receptor Mas. Proc Natl Acad Sci USA 100:8258-8263.

Sawzdargo M, Nguyen T, Lee DK, Lynch KR, Cheng R, Heng HH, George SR, and O'Dowd BF (1999) Identification and cloning of three novel human G proteincoupled receptor genes GPR52, PsiGPR53 and GPR55: GPR55 is extensively expressed in human brain. Brain Res Mol Brain Res 64:193-198.

Seal RL, Gordon SM, Lush MJ, Wright MW, and Bruford EA (2011) genenames.org the HGNC resources in 2011. Nucleic Acids Res 39:D514-D519.

Seuwen K, Ludwig MG, and Wolf RM (2006) Receptors for protons or lipid messengers or both? J Recept Signal Transduct Res 26:599-610.

Shah U and Kowalski TJ (2010) GPR119 agonists for the potential treatment of type 2 diabetes and related metabolic disorders. Vitam Horm 84:415-448.

Sharir H and Abood ME (2010) Pharmacological characterization of GPR55, a putative cannabinoid receptor. Pharmacol Ther 126:301-313.

Sharir H, Zinger A, Nevo A, Sekler I, and Hershfinkel M (2010) Zinc released from injured cells is acting via the $\mathrm{Zn} 2+$-sensing receptor, $\mathrm{ZnR}$, to trigger signaling leading to epithelial repair. J Biol Chem 285:26097-26106.

Sharman JL, Mpamhanga CP, Spedding M, Germain P, Staels B, Dacquet C, Laudet V, and Harmar AJ; NC-IUPHAR (2011) IUPHAR-DB: new receptors and tools for easy searching and visualization of pharmacological data. Nucleic Acids Res $\mathbf{3 9}$ (Database issue):D534-D538.

Sherry ST, Ward MH, Kholodov M, Baker J, Phan L, Smigielski EM, and Sirotkin K (2001) dbSNP: the NCBI database of genetic variation. Nucleic Acids Res 29 308-311.

Shinohara T, Harada M, Ogi K, Maruyama M, Fujii R, Tanaka H, Fukusumi S, Komatsu H, Hosoya M, and Noguchi Y, et al. (2004) Identification of a G proteincoupled receptor specifically responsive to beta-alanine. $J$ Biol Chem $\mathbf{2 7 9}$ 23559-23564.

Sierro F, Biben C, Martínez-Muñoz L, Mellado M, Ransohoff RM, Li M, Woehl B, Leung H, Groom J, and Batten M, et al. (2007) Disrupted cardiac development but normal hematopoiesis in mice deficient in the second CXCL12/SDF-1 receptor, CXCR7. Proc Natl Acad Sci USA 104:14759-14764.

Silva JP, Lelianova VG, Ermolyuk YS, Vysokov N, Hitchen PG, Berninghausen O, Rahman MA, Zangrandi A, Fidalgo S, and Tonevitsky AG, et al. (2011) Latrophilin 1 and its endogenous ligand Lasso/teneurin-2 form a high-affinity transsynaptic receptor pair with signaling capabilities. Proc Natl Acad Sci USA 108: $12113-12118$.

Singh G and Davenport AP (2006) Neuropeptide B and W: neurotransmitters in an emerging G-protein-coupled receptor system. $\mathrm{Br}$ J Pharmacol 148:1033-1041.

Soga T, Ohishi T, Matsui T, Saito T, Matsumoto M, Takasaki J, Matsumoto S, Kamohara M, Hiyama H, and Yoshida S, et al. (2005) Lysophosphatidylcholine enhances glucose-dependent insulin secretion via an orphan G-protein-coupled receptor. Biochem Biophys Res Commun 326:744-751.

Solinski HJ, Boekhoff I, Bouvier M, Gudermann T, and Breit A (2010) Sensory neuron-specific MAS-related gene-X1 receptors resist agonist-promoted endocytosis. Mol Pharmacol 78:249-259.

Southern C, Cook JM, Neetoo-Isseljee Z, Taylor DL, Kettleborough CA, Merritt A, Bassoni DL, Raab WJ, Quinn E, and Wehrman TS, et al. (2013) Screening $\beta$-arrestin recruitment for the identification of natural ligands for orphan Gprotein-coupled receptors. J Biomol Screen DOI: 10.1177/1087057113475480.

Stacey M, Chang GW, Davies JQ, Kwakkenbos MJ, Sanderson RD, Hamann J, Gordon S, and Lin HH (2003) The epidermal growth factor-like domains of the human EMR2 receptor mediate cell attachment through chondroitin sulfate glycosaminoglycans. Blood 102:2916-2924.

Starbäck P, Wraith A Eriksson H, and Larhammar D (2000) Neuropeptide Y receptor gene y6: multiple deaths or resurrections? Biochem Biophys Res Commun 277:264-269.

Stoddart LA, Smith NJ, and Milligan G (2008) International Union of Pharmacology. LXXI. Free fatty acid receptors FFA1, -2 , and -3 : pharmacology and pathophysiological functions. Pharmacol Rev 60:405-417.

Strotmann R, Schröck K, Böselt I, Stäubert C, Russ A, and Schöneberg T (2011) Evolution of GPCR: change and continuity. Mol Cell Endocrinol 331:170-178.

Sugiura T, Kondo S, Sukagawa A, Nakane S, Shinoda A, Itoh K, Yamashita A and Waku K (1995) 2-Arachidonoylglycerol: a possible endogenous cannabinoid receptor ligand in brain. Biochem Biophys Res Commun 215:89-97.

Sugo T, Tachimoto H, Chikatsu T, Murakami Y, Kikukawa Y, Sato S, Kikuchi K, Nagi T, Harada M, and Ogi K, et al. (2006) Identification of a lysophosphatidylserine receptor on mast cells. Biochem Biophys Res Commun 341:1078-1087.

Sumida H, Noguchi K, Kihara Y, Abe M, Yanagida K, Hamano F, Sato S, Tamaki K, Morishita Y, and Kano MR, et al. (2010) LPA4 regulates blood and lymphatic vessel formation during mouse embryogenesis. Blood 116:5060-5070.

Tabata K, Baba K, Shiraishi A, Ito M, and Fujita N (2007) The orphan GPCR GPR87 was deorphanized and shown to be a lysophosphatidic acid receptor. Biochem Biophys Res Commun 363:861-866.

Taggart AK, Kero J, Gan X, Cai TQ, Cheng K, Ippolito M, Ren N, Kaplan R, Wu K, and Wu TJ, et al. (2005) (D)-beta-Hydroxybutyrate inhibits adipocyte lipolysis via the nicotinic acid receptor PUMA-G. J Biol Chem 280:26649-26652.

Taniguchi Y, Tonai-Kachi H, and Shinjo K (2006) Zaprinast, a well-known cyclic guanosine monophosphate-specific phosphodiesterase inhibitor, is an agonist for GPR35. FEBS Lett 580:5003-5008

Thathiah A, Spittaels K, Hoffmann M, Staes M, Cohen A, Horré K, Vanbrabant M, Coun F, Baekelandt V, and Delacourte A, et al. (2009) The orphan G proteincoupled receptor 3 modulates amyloid-beta peptide generation in neurons. Science 323:946-951.

Thomas P, Pang Y, Filardo EJ, and Dong J (2005) Identity of an estrogen membrane receptor coupled to a $\mathrm{G}$ protein in human breast cancer cells. Endocrinology 146 : $624-632$

Tobo M, Tomura H, Mogi C, Wang JQ, Liu JP, Komachi M, Damirin A, Kimura T, Murata N, and Kurose H, et al. (2007) Previously postulated "ligand-independent" signaling of GPR4 is mediated through proton-sensing mechanisms. Cell Signal 19:1745-1753.

Toma I, Kang JJ, Sipos A, Vargas S, Bansal E, Hanner F, Meer E, and Peti-Peterdi J (2008) Succinate receptor GPR91 provides a direct link between high glucose levels and renin release in murine and rabbit kidney. J Clin Invest 118:2526-2534.

Toyooka M, Tujii T, and Takeda S (2009) The N-terminal domain of GPR61, an orphan G-protein-coupled receptor, is essential for its constitutive activity. $J$ Neurosci Res 87:1329-1333.

Tremblay F, Perreault M, Klaman LD, Tobin JF, Smith E, and Gimeno RE (2007) Normal food intake and body weight in mice lacking the $\mathrm{G}$ protein-coupled receptor GPR39. Endocrinology 148:501-506.

Tunaru S, Kero J, Schaub A, Wufka C, Blaukat A, Pfeffer K, and Offermanns S (2003) PUMA-G and HM74 are receptors for nicotinic acid and mediate its anti-lipolytic effect. Nat Med 9:352-355.

Uddin M and Levy BD (2011) Resolvins: natural agonists for resolution of pulmonary inflammation. Prog Lipid Res 50:75-88.

Uhlenbrock K, Gassenhuber H, and Kostenis E (2002) Sphingosine 1-phosphate is a ligand of the human gpr3, gpr6 and gpr12 family of constitutively active G protein-coupled receptors. Cell Signal 14:941-953.

Vanti WB, Muglia P, Nguyen T, Cheng R, Kennedy JL, George SR, and O'Dowd BF (2003) Discovery of a null mutation in a human trace amine receptor gene. Genomics 82:531-536.

Venkataraman C and Kuo F (2005) The G-protein coupled receptor, GPR84 regulates IL-4 production by T lymphocytes in response to CD3 crosslinking. Immunol Lett 101:144-153.

Waldeck-Weiermair M, Zoratti C, Osibow K, Balenga N, Goessnitzer E, Waldhoer M, Malli R, and Graier WF (2008) Integrin clustering enables anandamide-induced $\mathrm{Ca} 2+$ signaling in endothelial cells via GPR55 by protection against CB1-receptortriggered repression. J Cell Sci 121:1704-1717.

Wandel E, Saalbach A, Sittig D, Gebhardt C, and Aust G (2012) Thy-1 (CD90) is an interacting partner for CD97 on activated endothelial cells. $J$ Immunol 188 : $1442-1450$ 
Wang C, Dehghani B, Magrisso IJ, Rick EA, Bonhomme E, Cody DB, Elenich LA, Subramanian S, Murphy SJ, and Kelly MJ, et al. (2008) GPR30 contributes to estrogen-induced thymic atrophy. Mol Endocrinol 22:636-648.

Wang J, Simonavicius N, Wu X, Swaminath G, Reagan J, Tian H, and Ling L (2006a) Kynurenic acid as a ligand for orphan $\mathrm{G}$ protein-coupled receptor GPR35. J Biol Chem 281:22021-22028.

Wang J, Wu X, Simonavicius N, Tian H, and Ling L (2006b) Medium-chain fatty acids as ligands for orphan $\mathrm{G}$ protein-coupled receptor GPR84. J Biol Chem 281: 34457-34464. Epub 2006 Sep 11

Wang JQ, Kon J, Mogi C, Tobo M, Damirin A, Sato K, Komachi M, Malchinkhuu E, Murata N, and Kimura T, et al. (2004) TDAG8 is a proton-sensing and psychosinesensitive G-protein-coupled receptor. J Biol Chem 279:45626-45633.

Webb TE, Kaplan MG, and Barnard EA (1996) Identification of $6 \mathrm{H} 1$ as a P2Y purinoceptor: P2Y5. Biochem Biophys Res Commun 219:105-110.

Whyte LS, Ryberg E, Sims NA, Ridge SA, Mackie K, Greasley PJ, Ross RA and Rogers MJ (2009) The putative cannabinoid receptor GPR55 affects osteoclast function in vitro and bone mass in vivo. Proc Natl Acad Sci USA 106:16511-16516.

Williams JR, Khandoga AL, Goyal P, Fells JI, Perygin DH, Siess W, Parrill AL, Tigyi G, and Fujiwara Y (2009) Unique ligand selectivity of the GPR92/LPA5 lysophosphatidate receptor indicates role in human platelet activation. $J$ Biol Chem 284 $17304-17319$.

Wilson SR, Gerhold KA, Bifolck-Fisher A, Liu Q, Patel KN, Dong X, and Bautista DM (2011) TRPA1 is required for histamine-independent, Mas-related G protein coupled receptor-mediated itch. Nat Neurosci 14:595-602.

Wittamer V, Franssen JD, Vulcano M, Mirjolet JF, Le Poul E, Migeotte I, Brézillon S, Tyldesley R, Blanpain C, and Detheux M, et al. (2003) Specific recruitment of antigen-presenting cells by chemerin, a novel processed ligand from human inflammatory fluids. J Exp Med 198:977-985.

Witte ON, Kabarowski JH, Xu Y, Le LQ, and Zhu K (2005) Retraction. Science 307: 206.

Wyder L, Suply T, Ricoux B, Billy E, Schnell C, Baumgarten BU, Maira SM, Koelbing C, Ferretti M, and Kinzel B, et al. (2011) Reduced pathological angiogenesis and tumor growth in mice lacking GPR4, a proton sensing receptor. Angiogenesis 14: 533-544.

Xu L and Hynes RO (2007) GPR56 and TG2: possible roles in suppression of tumor growth by the microenvironment. Cell Cycle 6:160-165.

Yanagida K, Masago K, Nakanishi H, Kihara Y, Hamano F, Tajima Y, Taguchi R, Shimizu T, and Ishii S (2009) Identification and characterization of a novel lysophosphatidic acid receptor, p2y5/LPA6. J Biol Chem 284:17731-17741.

Yang LV, Radu CG, Roy M, Lee S, McLaughlin J, Teitell MA, Iruela-Arispe ML, and Witte ON (2007) Vascular abnormalities in mice deficient for the G proteincoupled receptor GPR4 that functions as a pH sensor. Mol Cell Biol 27:1334-1347.
Yang Y, Fu A, Wu X, and Reagan JD (2012) GPR35 is a target of the loop diuretic drugs bumetanide and furosemide. Pharmacology 89:13-17.

Yasuda S, Miyazaki T, Munechika K, Yamashita M, Ikeda Y, and Kamizono A (2007) Isolation of $\mathrm{Zn} 2+$ as an endogenous agonist of GPR39 from fetal bovine serum. J Recept Signal Transduct Res 27:235-246.

Yin H, Chu A, Li W, Wang B, Shelton F, Otero F, Nguyen DG, Caldwell JS, and Chen YA (2009) Lipid G protein-coupled receptor ligand identification using betaarrestin PathHunter assay. J Biol Chem 284:12328-12338.

Yoshida M, Miyazato M, and Kangawa K (2012) Orphan GPCRs and methods for identifying their ligands. Methods Enzymol 514:33-44.

Yoshimura T and Oppenheim JJ (2011) Chemokine-like receptor 1 (CMKLR1) and chemokine (C-C motif) receptor-like 2 (CCRL2); two multifunctional receptors with unusual properties. Exp Cell Res 317:674-684.

Zabel BA, Nakae S, Zúñiga L, Kim JY, Ohyama T, Alt C, Pan J, Suto H, Soler D, and Allen SJ, et al. (2008) Mast cell-expressed orphan receptor CCRL2 binds chemerin and is required for optimal induction of IgE-mediated passive cutaneous anaphylaxis. J Exp Med 205:2207-2220.

Zabel BA, Silverio AM, and Butcher EC (2005) Chemokine-like receptor 1 expression and chemerin-directed chemotaxis distinguish plasmacytoid from myeloid dendritic cells in human blood. J Immunol 174:244-251.

Zhang JV, Klein C, Ren PG, Kass S, Ver Donck L, Moechars D, and Hsueh AJ (2007) Response to Comment on "Obestatin, a peptide encoded by the ghrelin gene, opposes ghrelin's effects on food intake". Science 315:766d

Zhang JV, Ren PG, Avsian-Kretchmer O, Luo CW, Rauch R, Klein C, and Hsueh AJ (2005) Obestatin, a peptide encoded by the ghrelin gene, opposes ghrelin's effects on food intake. Science 310:996-999.

Zhang Y, Wang Z, Parks GS, and Civelli O (2011) Novel neuropeptides as ligands of orphan G protein-coupled receptors. Curr Pharm Des 17:2626-2631.

Zhang ZD, Frankish A, Hunt T, Harrow J, and Gerstein M (2010) Identification and analysis of unitary pseudogenes: historic and contemporary gene losses in humans and other primates. Genome Biol 11:R26.

Zhao P, Sharir H, Kapur A, Cowan A, Geller EB, Adler MW, Seltzman HH, Reggio PH, Heynen-Genel S, and Sauer M, et al. (2010) Targeting of the orphan receptor GPR35 by pamoic acid: a potent activator of extracellular signal-regulated kinase and $\beta$-arrestin2 with antinociceptive activity. Mol Pharmacol 78:560-568.

Zhu K, Baudhuin LM, Hong G, Williams FS, Cristina KL, Kabarowski JH, Witte ON, and Xu Y (2001) Sphingosylphosphorylcholine and lysophosphatidylcholine are ligands for the G protein-coupled receptor GPR4. J Biol Chem 276:41325-41335 [Retraction, 2005].

Zhu Y and Murakami F (2012) Chemokine CXCL12 and its receptors in the developing central nervous system: emerging themes and future perspectives. Dev Neurobiol 72:1349-1362. 